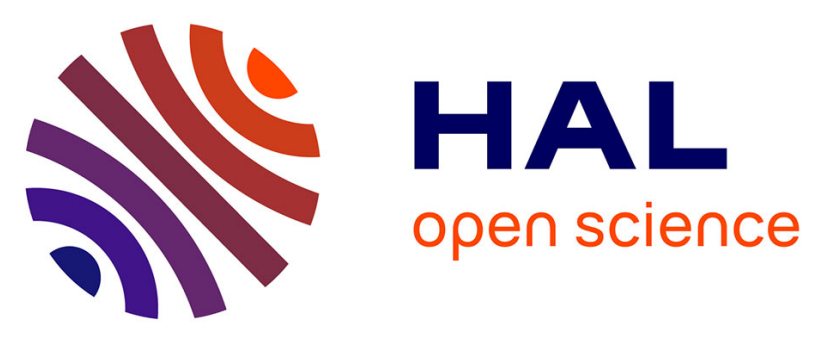

\title{
The Dynamics-Aerosol-Chemistry-Cloud Interactions in West Africa field campaign: Overview and research highlights
}

Cyrille Flamant, Peter Knippertz, Andreas H. Fink, Aristide Akpo, Barbara J. Brooks, Christine J. Chiu, Hugh Coe, Sylvester Danuor, Mat J. Evans, Oluwagbemiga Jegede, et al.

\section{To cite this version:}

Cyrille Flamant, Peter Knippertz, Andreas H. Fink, Aristide Akpo, Barbara J. Brooks, et al.. The Dynamics-Aerosol-Chemistry-Cloud Interactions in West Africa field campaign: Overview and research highlights. Bulletin of the American Meteorological Society, 2018, 99 (1), pp.83-104. 10.1175/BAMS-D-16-0256.1 . insu-01564453

\section{HAL Id: insu-01564453 \\ https://hal-insu.archives-ouvertes.fr/insu-01564453}

Submitted on 6 Mar 2020

HAL is a multi-disciplinary open access archive for the deposit and dissemination of scientific research documents, whether they are published or not. The documents may come from teaching and research institutions in France or abroad, or from public or private research centers.
L'archive ouverte pluridisciplinaire HAL, est destinée au dépôt et à la diffusion de documents scientifiques de niveau recherche, publiés ou non, émanant des établissements d'enseignement et de recherche français ou étrangers, des laboratoires publics ou privés.

\section{(ㄷ)(1) $(5$}

Distributed under a Creative Commons Attribution - NonCommerciall 4.0 International 


\section{THE DYNAMICS-AEROSOL- CHEMISTRY-CLOUD INTERACTIONS IN WEST AFRICA FIELD CAMPAIGN Overview and Research Highlights}

C. Flamant, P. Knippertz, A. H. Fink, A. Akpo, B. Brooks, C. J. Chiu, H. Coe, S. Danuor, M. Evans, O. Jegede, N. Kalthoff, A. Konaré, C. Liousse, F. Lohou, C. Mari, H. Schlager, A. Schwarzenboeck, B. Adler, L. Amekudzi, J. Aryee, M. Ayoola, A. M. Batendurg, G. Bessardon, S. Borrmann, J. Brito, K. Bower, F. Burnet, V. Catolre, A. Colomb, C. Denjean, K. Fosu-Amankwah, P. G. Hill, J. Lee, M. Lothon, M. Maranan, J. Marsham, R. Meynadier, J.-B. Ngamini, P. Rosenberg, D. Sauer, V. Smith, G. Stratmann, J. W. Taylor, C. Voigt, and V. Yoboué

\section{Unprecedented ground-based and aircraft measurements in southern West Africa} characterize atmospheric composition and dynamics, low-level cloud properties, the diurnal cycle, and air pollution impacts on health.

$\mathrm{T}$ ropical Africa is a region with particularly poor operational monitoring of the atmosphere and its constituents. Moreover, the observational network has been degraded in recent decades with many measurements being made using analog instruments failing to provide high-quality, highly resolved observations to the weather services and the research community. Advanced ground-based vertical profiling in situ and remote sensing systems, which have been installed in developed countries in recent decades, are-with very few exceptions-absent in tropical Africa. In addition, weather forecasting and climate models are known to have particular deficiencies in this region. For example, climate projections of rainfall in West Africa, as reviewed in the last Intergovernmental Panel on Climate Change assessment report (IPCC 2013), have not improved over the penultimate report. Finally, weather forecasts of convective rainfall show particularly poor skill in the West African region (e.g., Fink et al. 2011).

So far, very few field experiments have been conducted in sub-Saharan Africa, the largest of which were the Global Atmospheric Research Program (GARP) Atlantic Tropical Experiment (GATE; Kuettner 1974) and the African Monsoon Multidisciplinary Analysis (AMMA; Redelsperger et al. 2006, Lebel et al. 2010). The preparation and execution of such international field campaigns has proved to be extremely challenging. Yet, thanks to their rich and widely accessible databases, GATE and AMMA have advanced our understanding of the West African climate systems. In this article, the measurements made during the most recent large international field 
campaign in Africa, Dynamics-Aerosol-Chemistry-Cloud Interactions in West Africa (DACCIWA; www.dacciwa.eu; Knippertz et al. 2015a), are described along with preliminary research highlights.

The European Union (EU)-funded DACCIWA 2016 field campaign took place in southern West Africa (SWA) in June and July 2016, one year later than initially planned because of the Ebola epidemic, and involved upper-air, ground, and aircraft measurements in five West African countries. While AMMA focused on the Sahel and GATE on the eastern tropical Atlantic, DACCIWA targets the very densely populated and chemically diverse Guinea coastal region, which is currently undergoing rapid socioeconomic changes. An explosively growing population, massive urbanization, unregulated deforestation, and increasing anthropogenic emissions modify the composition of the atmosphere. Emissions from charcoal fires, traffic, and burning rubbish, as well as power plants, ship traffic, oil rigs, and tropical forest, influence atmospheric composition over SWA. In addition, monsoon winds bring sea salt and other oceanic compounds from the south, while large biomass burning (BB) plumes are advected from the Southern Hemisphere, and northerly winds bring dust from the Sahel and Sahara, making the air over the coastal region of West Africa a unique mixture of various gases and liquid and solid particles.
The atmospheric composition (gases and particles), the influence of anthropogenic pollutants and their secondary chemistry, as well as impacts on humans and ecosystems have never been studied in detail over this region.

At the same time, this region is characterized by complex meteorology. Multilayer cloud decks frequently form in this environment and exert a large influence on the local weather and climate, mainly due to their impact on radiation, the surface energy balance, and thus the diurnal cycle of the atmospheric boundary layer, which in turn is connected to the triggering of convection. In particular, the mechanisms involved in the formation and dissolution of clouds with bases below $300 \mathrm{~m}$ above ground level (AGL; e.g., Schuster et al. 2013) and midlevel clouds (Stein et al. 2011; Gounou et al. 2012) are not well understood to date, mostly because of a lack of adequate in situ and remote sensing observations. Furthermore, climate models are known to misrepresent low- and midlevel cloudiness in SWA, where the frequency and amount of such clouds is substantial, especially during late night and early morning hours (Van der Linden et al. 2015; Hannak et al. 2017). The supposed cooling effect of midlevel clouds is currently missing in global climate models (Bourgeois et al. 2016). Such errors and the lack of appropriate compositional observations
AfFiliations: Flamant and Meynadier-Laboratoire Atmosphères, Milieux, Observations Spatiales, Sorbonne Universités, UPMC Université Paris 06, UVSQ, and CNRS, Paris, France; KNIPPERTZ, Fink, Kalthoff, Adler, ANd Maranan-Institute of Meteorology and Climate Research, Karlsruhe Institute of Technology, Karlsruhe, Germany; AKPO-National Centre for Atmospheric Science, Leeds, United Kingdom; Brooks and Marsham-National Centre for Atmospheric Science, and University of Leeds, Leeds, United Kingdom; CHIU AND HILL-Department of Meteorology, University of Reading, Reading, United Kingdom; COE, BOWER, AND TAYLOR-School of Earth and Environmental Sciences, University of Manchester, Manchester, United Kingdom; DANUOR, AMEKUDZI, ARYeE, ANd Fosu-AmankwaH-Department of Physics, Kwame Nkrumah University of Science and Technology, Kumasi, Ghana; Evans AND Lee-Wolfson Atmospheric Chemistry Laboratories, National Centre for Atmospheric Science, University of York, York, United Kingdom; JegedE AND AYOOLA—Department of Physics and Engineering Physics, Obafemi Awolowo University, Ile-Ife, Nigeria; Konaré AND YobouÉ-Laboratoire de Physique de l'Atmosphère et de Mécanique des Fluides, Université of Cocody, Abidjan, Ivory Coast; LIOUSSE, LOHOU, MARI, AND LOTHON-Laboratoire d'Aérologie, Université de Toulouse, and CNRS, Toulouse, France; SCHLAGER, SAUER, and StRATMANN - Institut für Physik der Atmosphäre, Deutsches Zentrum für Luft- und Raumfahrt, Oberpfaffenhofen Wessling, Germany; SChWARZEnboeck, BRito, ANd Colomb-Laboratoire de Météorologie Physique, Université Blaise Pascal, CNRS,
Clermont-Ferrand, France; Batenburg AND BorRmanN-Max Planck Institute for Chemistry, Johannes Gutenberg University Mainz, Mainz, Germany; BesSARDON AND ROSENBERG-University of Leeds, Leeds, United Kingdom; Burnet AND DenJEAN-Centre National de Recherches Météorologiques, Météo-France, and CNRS, Toulouse, France; CATOIRE-Laboratoire de Physique et Chimie de l'Environnement et de l'Espace, Université d'Orléans, and CNRS, Orléans, France; NGAMINI-Agence pour la Sécurité de la Navigation Aérienne en Afrique et à Madagascar, Dakar, Senegal; SMITHNational Centre for Atmospheric Science, Leeds, United Kingdom; VoIGT-Institut für Physik der Atmosphäre, Deutsches Zentrum für Luft- und Raumfahrt, Oberpfaffenhofen Wessling, and Institut für Physik der Atmosphäre, University Mainz, Mainz, Germany CORRESPONDING AUTHOR: Cyrille Flamant,

cyrille.flamant@latmos.ipsl.fr

The abstract for this article can be found in this issue, following the table of contents.

DOI:10.1I75/BAMS-D-16-0256.I

A supplement to this article is available online (10.II75/BAMS-D-16-0256.2)

In final form 30 June 2017

C2018 American Meteorological Society

For information regarding reuse of this content and general copyright

information, consult the AMS Copyright Policy. 


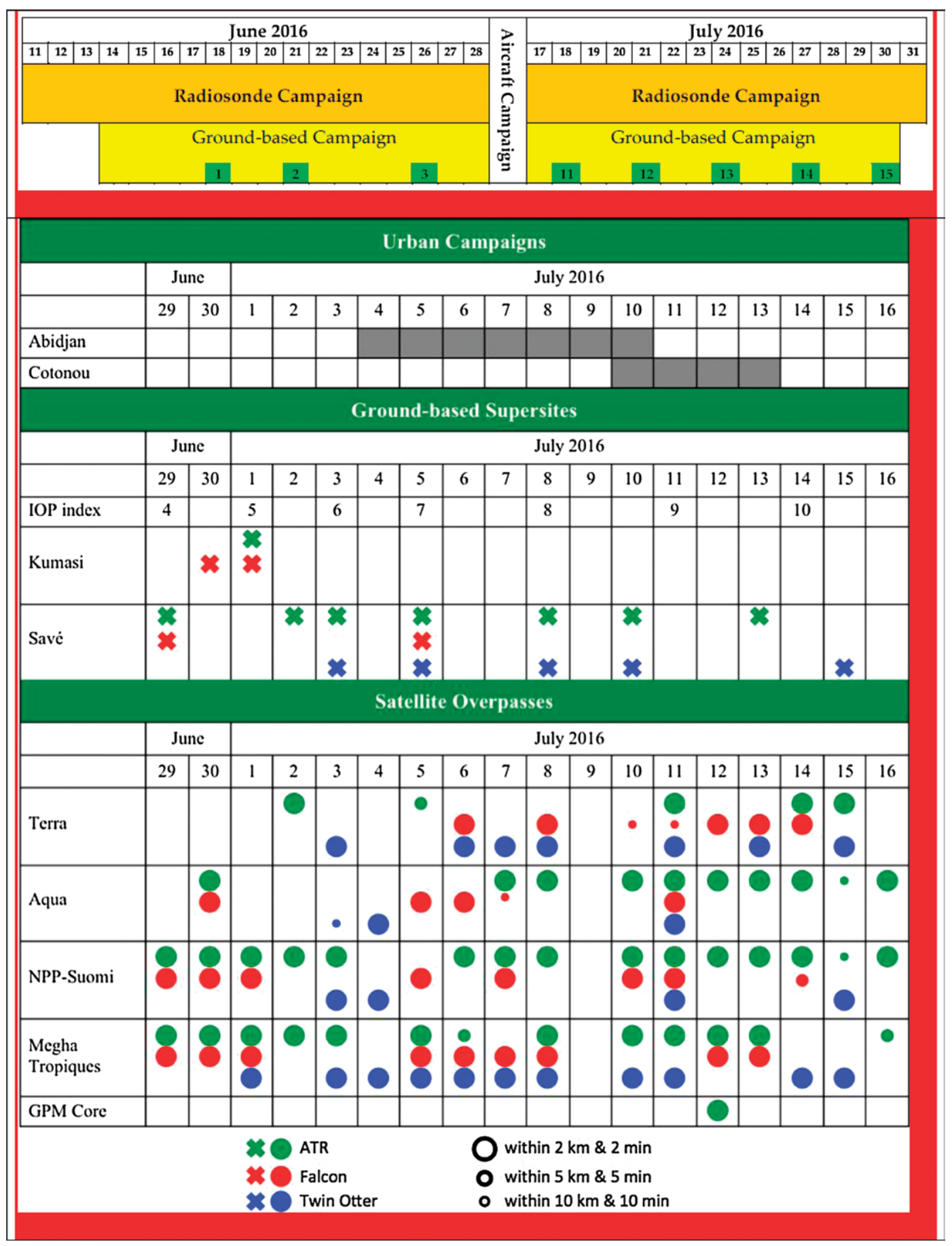

FIG I. (top) Overview of the timeline of the DACCIWA campaign and its components. The DACCIWA radiosounding campaign (orange) took place between II Jun and 31 Jul 2016 (see Figs. ES4-ES6), while the groundbased campaign (yellow) took place between 14 Jun and $30 \mathrm{Jul}$ 2016. IOPs conducted at the ground-based supersites prior to and after the aircraft campaign (29 Jun-16 Jul 2016) are indicated in green (numbers correspond to IOP numbers). (middle) Timeline of the aircraft campaign with duration of the urban campaigns in Abidjan and Cotonou, and the list of ground-based supersite IOPs conducted during this period. Colored crosses indicate when the airborne platforms (ATR42, Falcon 20, and Twin Otter) flew in the vicinity of the supersites. (bottom) A summary of satellite overpasses, including the Moderate Resolution Imaging Spectroradiometer (MODIS) aboard Terra and Aqua, the Visible Infrared Imaging Radiometer Suite (VIIRS) aboard Suomi National Polar-Orbiting Partnership (NPP), the Megha-Tropiques, and the Global Precipitation Measurement Core Observatory (GPM Core). Colors represent various platforms, while sizes of the filled circles provide an indication of whether the distance and the time between the aircraft track and the nearest satellite pixel meet the given thresholds. 


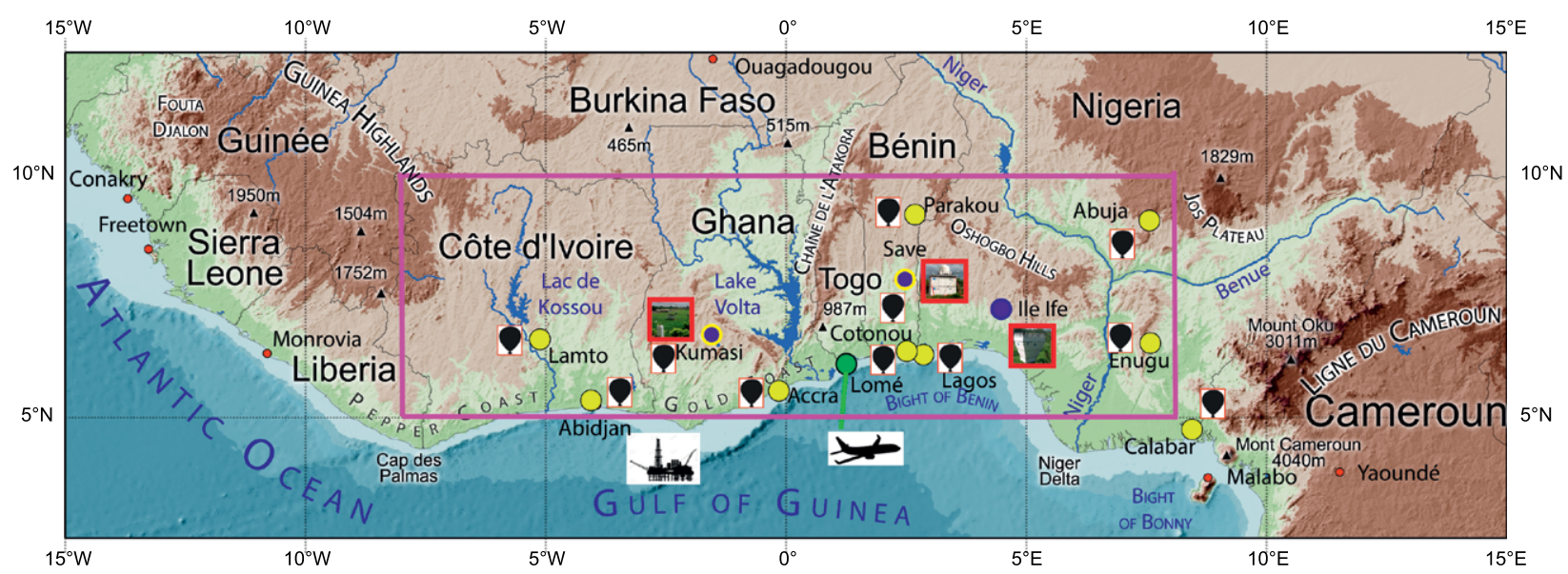

FIg. 2. Geographical overview with key landmarks for the DACCIWA campaign operations overlain on topography. The yellow symbols represent radiosounding stations and the blue symbols are ground-based supersites. The yellow-circled blue symbols indicate supersites with balloon sounding capability. The green symbol shows the location of the aircraft operation base (linked with an aircraft schematic). The oil and gas field locations offshore of Ghana and Ivory Coast are symbolized with an oil rig schematic.

hinder advancing our knowledge of chemistry-aerosol-cloud interactions in such a complex chemical environment (Knippertz et al. 2015b).

A review of the meteorological and chemical measurements made during the field campaign (see Fig. 1 for the timeline of the DACCIWA experiment) and some preliminary results are presented in this paper with the aim to make researchers aware of a new rich experimental dataset for SWA. We expect that DACCIWA data will widely be used by researchers around the world in the next two decades. The meteorological and chemical conditions during the campaign are presented in Knippertz et al. (2017). As part of this campaign, three research aircraft based in Togo flew targeted coordinated missions over SWA (Fig. 2). The "Aircraft campaign" section presents the aircraft capabilities and the flight objectives. In addition to the flights, DACCIWA scientists set up three highly instrumented measuring sites inland in Ghana, Benin, and Nigeria. The instruments deployed on the ground and the experimental strategies are detailed in "Ground-based campaign." A coordinated effort to launch weather balloons several times a day across the region was also conducted. The network of operational stations and stations specifically set up at DACCIWA sites are described in "Radiosonde campaign." Urban emissions were measured in Abidjan, Ivory Coast, and Cotonou, Benin, and health data were evaluated in Abidjan, which are reported in "Urban campaign." The field campaign was supported by a satellite component that is described in "Satellite." Finally, selected campaign highlights are presented in an integrative framework in "Campaign highlights" and conclusions are given in "Conclusions and outlook."
AIRCRAFT CAMPAIGN. The main objective for the aircraft detachment was to build robust statistics of cloud properties in SWA in different chemical landscapes: from the background state over the Gulf of Guinea (marine aerosols or mix between marine aerosols and $\mathrm{BB}$ aerosols from the Southern Hemisphere) to ship/flaring emissions to the coastal strip of polluted multimillion-inhabitant cities to the agricultural areas and forest areas farther north, and eventually dust from the Sahel and/or Sahara. An ancillary objective of the detachment was to contribute to the reduction of uncertainties on emissions from big cities, ships, and oil rigs, as well as biogenic emissions from vegetation. Flight activities were coordinated with the ground-based ("Ground-based campaign" section) and urban components ("Urban campaign" section).

The project brought together three research aircraft from three countries: the German Deutsches Zentrum für Luft- und Raumfahrt (DLR) Falcon 20, the French Service des Avions Français Instrumentés pour la Recherche en Environnement (SAFIRE) ATR 42, and the British Antarctic Survey (BAS) Twin Otter (Figs. 3 and ES1-ES3; more information can be found online at https://doi.org/I0.II75/BAMS -D-16-0256.2). Scientific flights took place between 29 June and 16 July 2016 (Fig. 1). The entire aircraft detachment fell into the so-called postonset period (see Knippertz et al. 2017), with a well-established monsoon and thus relatively dry conditions along the Gulf of Guinea coast with frequent formation of low clouds. The three research aircraft were deployed from the Lomé Military Airport (Togo) and conducted a total of over 155 science flight hours (Table 1), including 

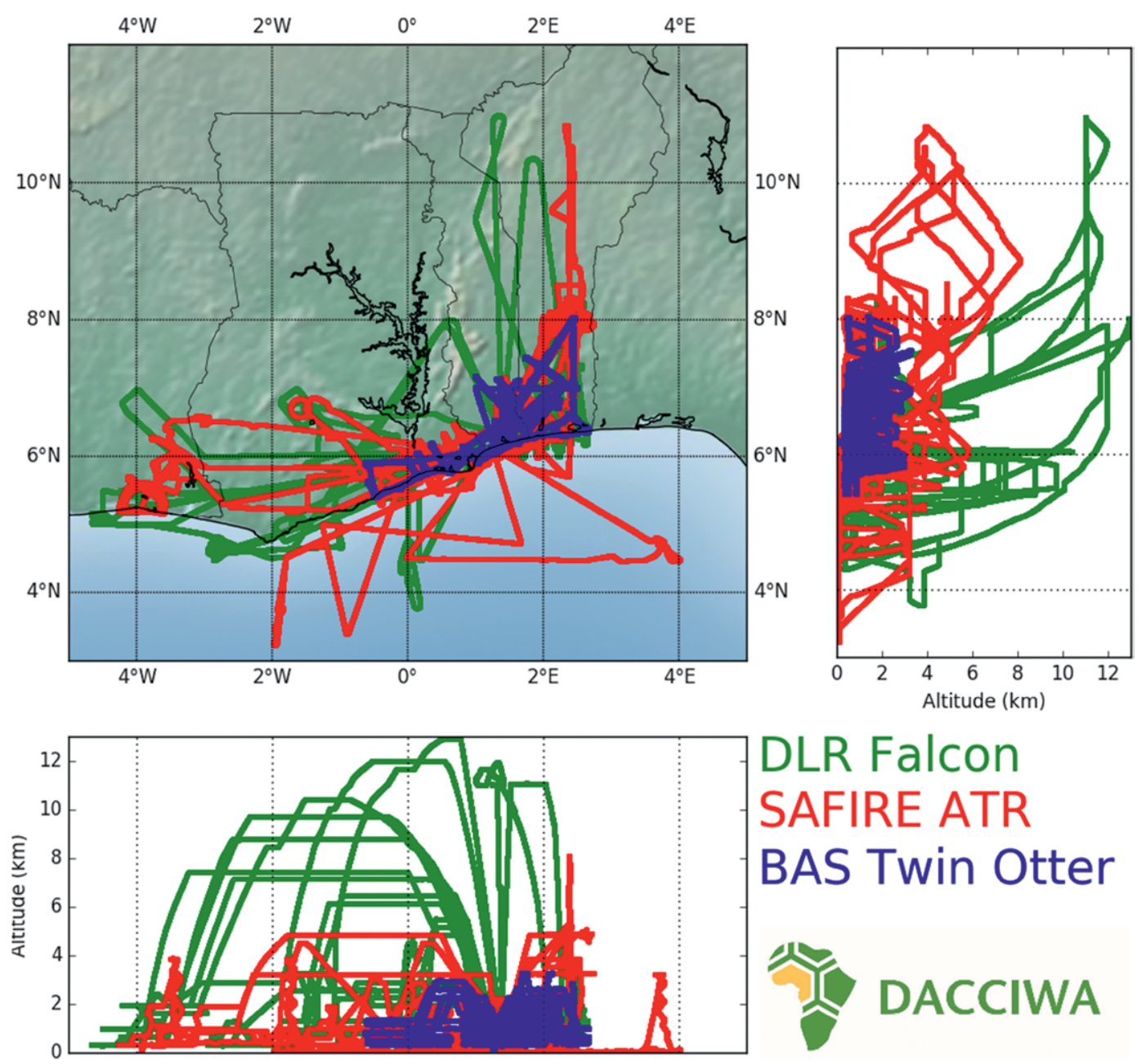

FIG. 3. (top left) Latitude-longitude representation of flight tracks of all aircraft (50 in total) over SWA between 29 Jun and 16 Jul 2016: the DLR Falcon 20 flight tracks ( 12 flights) are in green, the SAFIRE ATR 42 flight tracks (20 flights) are in red, and the BAS Twin Otter tracks ( 18 flights) are in blue. (top right) Altitude-latitude representation of all aircraft flight tracks. (bottom left) Altitude-longitude representation of all aircraft flight tracks.

hours sponsored through three European Facility for Airborne Research (EUFAR) projects (see Table 1). The aircraft were used in different ways based on their strengths, but all three had comparable instrumentation with the capability to measure general meteorology, gas-phase chemistry, aerosols, and clouds, thereby generating a rich dataset of atmospheric conditions across the region (see Tables ES2-ES4 for detailed payloads for each aircraft).

Flights were coordinated from the DACCIWA Operations Center (DOC; http://dacciwa.sedoo.fr/) located in Lomé, Togo. The DOC began operations on 25 June to prepare forecasts for the first potential flight operations and to test communications with the ground-based supersites in Savè (Benin), Kumasi (Ghana), and Ile-Ife (Nigeria). Throughout the campaign, the aircraft flights were monitored live from the DOC, in liaison with the ground-based facilities. Two daily briefing meetings were organized at the DOC during the period of the aircraft detachment, at 1100 and 1900 UTC between 25 June and 15 July, which included overviews of the meteorology and chemistry/aerosol conditions prepared by the forecast team (composed of DACCIWA scientists and agents from the Direction Générale de la Météorologie Nationale Togo).

Eight types of flight objectives were conducted over Togo and the neighboring countries of Ivory Coast, Ghana, and Benin (see Fig. 2 and Table ES5):

1) Low-level clouds (LLCs): Describe the atmospheric dynamics, thermodynamics, radiation, composition, and LLC properties inland along the monsoon flow and document the diurnal cycle of all these variables, as they evolved from stratus to stratocumulus to cumulus or cumulus congestus. Based on the stratus cloud 
TABLE I. Aircraft information and science flight hours completed. For altitude, note that Ift $\approx 0.305 \mathrm{~m}$, and for range note that I $\mathrm{n} \mathrm{mi}=1.852 \mathrm{~km}$.

\begin{tabular}{|c|c|c|c|}
\hline & SAFIRE ATR 42 & DLR Falcon & BAS Twin Otter \\
\hline Availability in Lomé & 27 Jun-16 Jul & 27 Jun-14 Jul & 27 Jun-16 Jul \\
\hline \multirow{3}{*}{$\begin{array}{l}\text { Science flight duration } \\
\text { (including EUFAR) }\end{array}$} & 67 h $49 \mathrm{~min}$ & $40 \mathrm{~h} 34 \mathrm{~min}$ & 46 h $45 \mathrm{~min}$ \\
\hline & MICWA: $^{\text {a }} 12$ h 45 min & APSOWAc: $^{c}$ II h $6 \mathrm{~min}$ & \\
\hline & OLACTA $^{\mathrm{b}}: 10 \mathrm{~h} 12 \mathrm{~min}$ & & \\
\hline \multirow{3}{*}{ No. of science flights } & 20 & 12 & 18 \\
\hline & MICWA: 3 & APSOWA: 3 & \\
\hline & OLACTA: 3 & & \\
\hline Altitude range (ft) & $200-25,000$ & $500-34,000$ & $1,000-10,000$ \\
\hline Duration & $3 \mathrm{~h} 30 \mathrm{~min}$ & $3 \mathrm{~h} 30 \mathrm{~min}$ & $4 \mathrm{~h}$ \\
\hline Range (n mi) & 650 & 1,500 & 480 \\
\hline Speed $\left(\mathrm{m} \mathrm{s}^{-1}\right)$ & 100 & $100-255$ & $47-64$ \\
\hline
\end{tabular}

a Mid-level Clouds over West Africa (MICWA).

b Observing the Low-level Atmospheric Circulation in the Tropical Atlantic (OLACTA).

c Air Pollution from Shipping and Oil Platforms of West Africa (APSOWA).

climatology reported in Van der Linden et al. (2015), two preferred regions of operations were selected: i) over southern Ghana and Ivory Coast, where satellite observations show the highest occurrence frequency, and ii) over Benin, where stratus clouds are observed often as well, but not as extensively as those over Ivory Coast. The flights were organized along three axes: i) Lomé-Savè, ii) Lomé-Accra-Kumasi, and iii) Lomé-Abidjan (see Fig. 2 and Table ES8). The former two flights allowed liaising aircraft measurements with observations at the Savè and Kumasi supersites. Stratus cloud properties were sampled both within and outside of the pollution plumes of major cities.

2) Land-sea-breeze clouds: Document the impact of land-sea-breeze clouds on the scavenging and ventilation of pollutants (chemical compounds and aerosols) along the monsoon flow, downstream of the urbanized coastal strip.

3) Biogenic emission: Document biogenic gaseous and aerosol emissions across and along the southnorth climatological gradient of vegetation in SWA (including primary forests) and downstream of major polluted cities to study the interaction of biogenic and anthropogenic aerosols (see Table ES6).

4) City emissions: Document the atmospheric dynamics, thermodynamics, radiation, and composition upstream and downstream of polluted coastal cities (both budget and aging type analyses) (see Table ES6). For the sake of robust statistics, only a few big cities (Accra, Kumasi,
Lomé, Cotonou, and Abidjan) were targeted. Coordination with the urban emission campaign in Abidjan (see "Urban campaign" section) was achieved.

5) Dust and BB aerosols: Document the plumes from fires in the Southern Hemisphere and dust aerosol from Saharan and/or Sahelian sources transported to SWA and likely impacting the air quality in and around cities and the life cycle of stratus (through direct radiative or indirect effects) (see Table ES7).

6) Air Pollution from Shipping and Oil Platforms of West Africa (APSOWA), funded by EUFAR: Characterize the gaseous and particulate pollutants emitted by shipping and oil/gas extraction platforms (Jubilee oil field offshore of Ghana and Espoir; Panther and Lion oil fields offshore of Ivory Coast; see Fig. 2 and Table ES5).

7) Mid-Level Clouds over West Africa (MICWA), funded by EUFAR: Document dynamic/thermodynamic genesis and lysis processes of midlevel cloud decks in order to understand the respective roles of radiative, turbulence, and synoptic-scale subsidence processes.

8) Observing the Low-Level Atmospheric Circulation in the Tropical Atlantic (OLACTA), funded by EUFAR: Document low-level atmospheric circulation over the Gulf of Guinea, which develops in response to an equatorial upwelling, and has a significant impact on air-sea interactions, moisture transport, cloud development, and pollution ventilation in the coastal areas of SWA (Leduc-Leballeur et al. 2013). 
Flight plans were engineered such that they could accommodate several objectives (e.g., stratus and land-sea-breeze clouds and urban vs biogenic emissions). Times, locations, and scientific objectives of all flights conducted during the campaign are given in Table ES5. Instrument calibration and intercomparison exercises were also conducted to identify problems and assess differences between similar instruments embarked on the different aircraft, using specifically designed protocols for i) aerosols and clouds, ii) chemistry, and iii) radiation.

GROUND-BASED CAMPAIGN. LLCs are of primary importance for the regional weather, climate, and air quality owing to radiative effects, impacts on the convective boundary layer (CBL) development, and interactions with pollutants. The ground-based campaign was conducted in areas strongly affected by LLCs. Measurements were designed to identify the controlling processes and factors for LLC formation and to investigate LLC effects on CBL conditions.

Intensive measurements were performed from 14 June to 30 July 2016 (Fig. 1) at three supersites forming a west-east transect along the Guinean coast: Kumasi (Ghana), Savè (Benin), and Ile-Ife (Nigeria) (Fig. 2):

1) The Kumasi site $\left[6^{\circ} 40^{\prime} 48.56^{\prime \prime} \mathrm{N}, 1^{\circ} 33^{\prime} 37.76^{\prime \prime} \mathrm{E}\right.$, $266 \mathrm{~m}$ above sea mean level (MSL)] on the campus of Kwame Nkrumah University of Science and Technology (KNUST) was operated by the National Centre for Atmospheric Science (NCAS) with assistance from KNUST.

2) The site at Savè $\left(8^{\circ} 00^{\prime} 03.6^{\prime \prime} \mathrm{N}, 2^{\circ} 25^{\prime} 41.1^{\prime \prime} \mathrm{E}, 166 \mathrm{~m}\right.$ MSL) was jointly operated by Karlsruhe Institute of Technology (KIT) and Université Toulouse III-Paul Sabatier, Laboratoire d'Aérologie (UPS), and hosted by Institut National de Recherche Agronomique du Benin (INRAB). Some instruments were deployed at the Savè airfield $\left(8^{\circ} 01^{\prime} 04.4^{\prime \prime} \mathrm{N}, 2^{\circ} 27^{\prime} 50.8^{\prime \prime} \mathrm{E}, 180 \mathrm{~m}\right.$ MSL), located $4 \mathrm{~km}$ east of the INRAB site.

3) The Ile-Ife site $\left(7^{\circ} 33^{\prime} 11.52^{\prime \prime} \mathrm{N}, 4^{\circ} 33^{\prime} 26.70^{\prime \prime} \mathrm{E}, 274 \mathrm{~m}\right.$ MSL) was on the campus of Obafemi Awolowo University (OAU), at the same location as the permanent meteorological station, OAU-Met.

A comprehensive set of instruments was deployed at the three sites (Table ES10). Capacity building efforts were undertaken at the Savè and Kumasi supersites, involving operational and academic research partners, as well as students when possible. Surface stations measuring the mean meteorological parameters, surface radiation and energy balance components, and soil temperature and humidity provided the lower boundary conditions and, at the same time, the LLCs' impact on the radiation balance at the surface. Thermodynamics and dynamics in the lower atmosphere were monitored continuously by active (wind profilers, Doppler lidars, sodars) and passive (microwave radiometers) remote sensing systems. In addition to radiosondes launched at synoptic times, tethered radiosondes in Ile-Ife and frequent radiosondes in Kumasi and Savè were launched in regular intervals during intensive operation periods (IOPs). These measurements focus on the detection of the nocturnal low-level jet (LLJ), monsoon and harmattan flows, African easterly jet (AEJ), and the tropospheric stratification. Cloud characteristics, such as cloud base, top, and cover, as well as the spatial and temporal evolution of precipitation and cloud drop size distribution, were monitored by a set of in situ and remote sensing devices (distrometers, rain gauges, cloud radar, rain radar, infrared radiometer, cloud camera). Chemistry and aerosol measurements complete this dataset. Finally, two remotely piloted aircraft systems (RPASs), Aladina and Ovli, were operated in Savè during the aircraft campaign by Innovationsgesellschaft Technische Universität Braunschweig. All measured parameters are listed in Table ES10. The applied measurement strategy (e.g., scan patterns and radiosounding frequency) was optimized to capture various atmospheric processes expected from high-resolution simulations performed in preparation of the campaign. These include horizontal advection from the Guinea coast and triggering of new clouds upstream of existing clouds due to an upward shift of the LLJ in cloudy areas (Adler et al. 2017).

The ground-based campaign started two weeks before and continued for two weeks after the aircraft campaign. During this period, all systems were operated continuously, except the radiosondes and the RPASs. In Kumasi and Savè, radiosondes were launched every morning at 0600 UTC. This time was selected because the LLC cover was expected to be largest. In total, 15 IOPs were conducted at all three sites, 7 of which were during the aircraft campaign (see Fig. 1), running for $24 \mathrm{~h}$ from 1800 UTC. During an IOP, four radiosondes were launched every $6 \mathrm{~h}$ and frequent or tethered radiosoundings were performed in between, every $1-3 \mathrm{~h}$ depending on the supersite. In Savè, RPAS Ovli flew vertical profiles in the afternoon during periods when no frequent radiosoundings were launched. RPAS Aladina, equipped with a turbulence probe, performed flight patterns consisting of vertical profiles and horizontal legs during periods when LLCs 
TABLE 2. List of DACCIWA campaign and NIMET operational radiosonde stations, operating agency, sonde type, and launch times. Stations in italics are operational upper-air stations. Acronyms and their expansions include Agence pour la Sécurité de la Navigation Aérienne en Afrique et à Madagascar (ASECNA), Société de Développement et d'Exploitation Aéroportuaire et Maritime (SODEXAM), Direction National de la Météorologie (DNM), Nigerian Meteorological Agency (NIMET), Ivory Coast (IC), Université Félix Houphouët-Boigny (UFHB), Kwame Nkrumah University of Science and Technology (KNUST), Ghana Meteorological Agency (GMET), Karlsruhe Institute of Technology (KIT), and Université Paul Sabatier (UPS).

\begin{tabular}{|c|c|c|c|c|c|c|c|}
\hline $\begin{array}{l}\text { Station } \\
\text { (country) }\end{array}$ & $\begin{array}{c}\text { WMO No. or } \\
\text { mobile TEMP } \\
\text { name }\end{array}$ & Lat & Lon & $\begin{array}{l}\text { Altitude } \\
\quad(\mathrm{m})\end{array}$ & Operator & Sonde & $\begin{array}{l}\text { Campaign } \\
\text { launch time } \\
\text { (UTC) }\end{array}$ \\
\hline \multirow{2}{*}{$\begin{array}{l}\text { Abidjan } \\
\text { (IC) }\end{array}$} & \multirow[t]{2}{*}{65578} & \multirow[t]{2}{*}{$5^{\circ} 15^{\prime} \mathrm{N}$} & \multirow[t]{2}{*}{$3^{\circ} 56^{\prime} \mathrm{W}$} & \multirow[t]{2}{*}{7} & \multirow{2}{*}{$\begin{array}{l}\text { SODEXAM/ } \\
\text { ASECNA }\end{array}$} & MODEM & \multirow{2}{*}{$\begin{array}{c}0000,0600,1200, \\
1800\end{array}$} \\
\hline & & & & & & MIO & \\
\hline \multirow{2}{*}{$\begin{array}{l}\text { Cotonou } \\
\text { (Benin) }\end{array}$} & \multirow[t]{2}{*}{65344} & \multirow[t]{2}{*}{$6^{\circ} 2 I^{\prime} \mathrm{N}$} & \multirow[t]{2}{*}{$2^{\circ} 23^{\prime} E$} & \multirow[t]{2}{*}{5} & \multirow{2}{*}{$\begin{array}{l}\text { DNM Benin/ } \\
\text { ASECNA }\end{array}$} & MODEM & \multirow{2}{*}{$\begin{array}{c}0000,0600,1200 \\
1800\end{array}$} \\
\hline & & & & & & MIO & \\
\hline \multirow{2}{*}{$\begin{array}{l}\text { Parakou } \\
\text { (Benin) }\end{array}$} & \multirow[t]{2}{*}{ BJPAR } & \multirow[t]{2}{*}{$9^{\circ} 2 I^{\prime} \mathrm{N}$} & \multirow[t]{2}{*}{$2^{\circ} 37^{\prime} E$} & \multirow[t]{2}{*}{392} & \multirow{2}{*}{$\begin{array}{l}\text { DNM Benin/ } \\
\text { ASECNA }\end{array}$} & MODEM & \multirow{2}{*}{$\begin{array}{c}0000,0600,1200 \\
1800\end{array}$} \\
\hline & & & & & & MIO & \\
\hline \multirow{2}{*}{$\begin{array}{l}\text { Kumasi } \\
\text { (Ghana) }\end{array}$} & \multirow[t]{2}{*}{ GHKUM } & \multirow[t]{2}{*}{$6^{\circ} 40^{\prime} \mathrm{N}$} & \multirow[t]{2}{*}{$1^{\circ} 33^{\prime} \mathrm{W}$} & \multirow[t]{2}{*}{279} & \multirow{2}{*}{$\begin{array}{l}\text { University of } \\
\text { Leeds/KNUST }\end{array}$} & Vaisala & 0600 (every day) \\
\hline & & & & & & MW4I & $\begin{array}{c}0000,1200,1800 \\
\text { (IOP days) }\end{array}$ \\
\hline \multirow{2}{*}{$\begin{array}{l}\text { Savé } \\
\text { (Benin) }\end{array}$} & \multirow[t]{2}{*}{ LA-Save } & \multirow[t]{2}{*}{$8^{\circ} 00^{\prime} \mathrm{N}$} & \multirow[t]{2}{*}{$2^{\circ} 26^{\prime} \mathrm{E}$} & \multirow[t]{2}{*}{166} & \multirow[t]{2}{*}{ UPS/KIT } & MODEM & 0600 (every day) \\
\hline & & & & & & MIO & $\begin{array}{c}0000,1200,1800 \\
\text { (IOP days) }\end{array}$ \\
\hline \multirow{2}{*}{$\begin{array}{l}\text { Accra } \\
\text { (Ghana) }\end{array}$} & \multirow[t]{2}{*}{ GHACC } & \multirow[t]{2}{*}{$5^{\circ} 42^{\prime} \mathrm{N}$} & $0^{\circ} 0 \mathrm{I}^{\prime} \mathrm{W}$ & 84 & GMET/KIT & GRAW & $0000,0600,0900$, \\
\hline & & & & & & DFM09 & 1200,1800 \\
\hline Lamto & IVLAM & $6^{\circ} 13^{\prime} \mathrm{N}$ & $5^{\circ} 0 I^{\prime} \mathrm{W}$ & 155 & UFHB/KIT & GRAW & $0000,0600,0900$ \\
\hline$(I C)$ & & & & & & DFM09 & 1200,1800 \\
\hline $\begin{array}{l}\text { Lagos } \\
\text { (Nigeria) }\end{array}$ & 65202 & $6^{\circ} 33^{\prime} \mathrm{N}$ & $3^{\circ} 20^{\prime} \mathrm{E}$ & 19 & NIMET & GRAW DFM 09 & 1200 \\
\hline $\begin{array}{c}\text { Enugu } \\
\text { (Nigeria) }\end{array}$ & 65257 & $6^{\circ} 28^{\prime} \mathrm{N}$ & $7^{\circ} 33^{\prime} \mathrm{E}$ & 137 & NIMET & MODEM MIO & 1200 \\
\hline $\begin{array}{c}\text { Abuja } \\
\text { (Nigeria) }\end{array}$ & 65125 & $9^{\circ} 15^{\prime} \mathrm{N}$ & $7^{\circ} 00^{\prime} \mathrm{E}$ & 344 & NIMET & VAISALA RS92 & 1200 \\
\hline $\begin{array}{l}\text { Calabar } \\
\text { (Nigeria) }\end{array}$ & 65264 & $4^{\circ} 58^{\prime} \mathrm{N}$ & $8^{\circ} 21^{\prime} \mathrm{E}$ & 63 & NIMET & GRAW DFM 09 & 1200 \\
\hline
\end{tabular}

were present in the morning, when the LLCs were breaking up, and in the evening during the transition phase toward stable conditions.

During the seven weeks of measurements, LLCs were observed almost every night at the three sites. However, strong variations in the spatiotemporal characteristics of LLCs and LLJs occurred not only between the different supersites, but also from day to day at the individual sites. The cloud-base height varied from near the ground to several hundred meters AGL, and the vertical extent ranged from several hundred to more than a thousand meters. LLC formation occurred between 2000 and 0600 UTC. LLCs normally started to lift simultaneously with the growth of the CBL and broke up progressively in the early afternoon. This strong variability is supposed to be associated with, for example, the nocturnal LLJ strength and depth, the transition layer between the monsoon flow and harmattan, the atmospheric stratification, and the position of the AEJ and the existence of mid- and upper-level clouds. These parameters change on daily to monthly scales.

RADIOSONDE CAMPAIGN. Operational upper-air stations are very sparsely distributed over West Africa, resulting in a need to enhance upper-air observations during the DACCIWA experimental period. Building on the experience during AMMA (cf. Parker et al. 2008), existing infrastructure, and personal connections, the upper-air network was successfully augmented during June and July 2016 to a spatial density unprecedented for SWA. From 


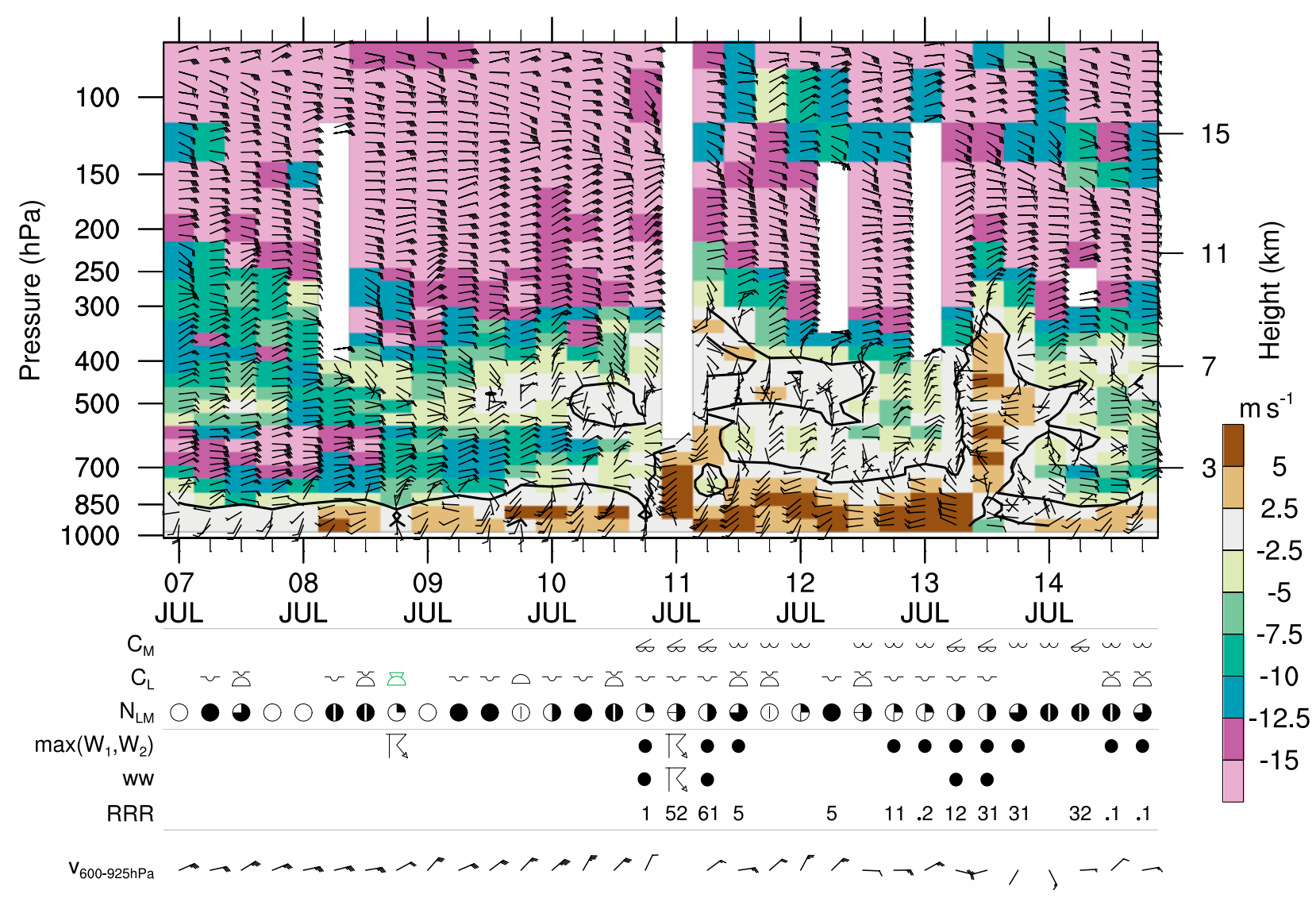

FIG. 4. Time-height diagram showing the evolution of the vertical wind regime at Parakou (Benin) from 9 to 16 Jul 2016. Plotted are 6-hourly vertical profiles of zonal wind speed ( $\mathrm{m} \mathrm{s}^{-1}$; colored raster) and wind barbs with short and long ticks indicating 5 and 10 knots, respectively $(\mathrm{l} \mathrm{kt}=0.5 \mathrm{I} \mathrm{m} \mathrm{s}$ ), and a filled triangle $50 \mathrm{kt}$. Thick contour indicates zero zonal wind speed. Vertical resolution is every $\mathbf{2 5} \mathrm{hPa}$ for wind speed and $300 \mathrm{~m}$ for wind barbs (left ordinate) with corresponding altitude in kilometers ( right ordinate). Symbols below the abscissa are according to WMO FM 12 SYNOP coding practices for surface stations (WMO 2010) and denote the following: midlevel cloud type $C_{M}$, low-level cloud type $C_{L}$, low- and midlevel cloud cover in octas $N_{L M}$, significant weather (WW), and rainfall amount ( $\mathrm{mm}$; RRR). Rainfall is accumulated over previous 24,12 , and $6 \mathrm{~h}$ for 0600 , I800, and 0000/I200 UTC observation times, respectively.

its outset, the DACCIWA radiosonde campaign had three pillars: i) enhancing soundings at operational or quiescent AMMA radiosonde stations, ii) launching sondes at DACCIWA supersites and two additional DACCIWA field sites, and iii) collecting standard and-if possible-high-resolution data from other operational radiosounding stations.

During the precampaign investigation of the status of operational stations, three surprises were encountered. First, the Vaisälä ground station furnished in 2006 by AMMA to the Nigerian Meteorological Agency (NIMET) station of Abuja (see Table 2 for WMO number) was in operational use; Abuja regularly conducted 1200 UTC soundings, but hardly any of them were received on the Global Telecommunication System (GTS) because of transmission problems. Second, Cotonou resumed 1200 UTC soundings in September 2012 using the
MODEM ground station provided by AMMA. However, while being on the GTS, the use of TEMPS from Cotonou in databases and weather prediction appeared to be impeded by missing meta information. Third, NIMET operated four additional radiosonde stations at Lagos, Kano, Enugu, and Calabar (see Fig. ES4 for station locations), from which only Kano TEMPs sporadically appeared on the GTS before the campaign.

The management of soundings at Abidjan, Cotonou, and Parakou (Benin) was subcontracted to a private company with a success rate of almost $100 \%$ (Figs. ES5 and ES6). The existing collaboration with the Ghana Meteorological Agency (GMET) enabled us to conduct experimental soundings at their headquarters in Accra. In cooperation with the Lamto Geophysical Observatory and the Université Félix Houphouët-Boigny, radiosondes were launched at 

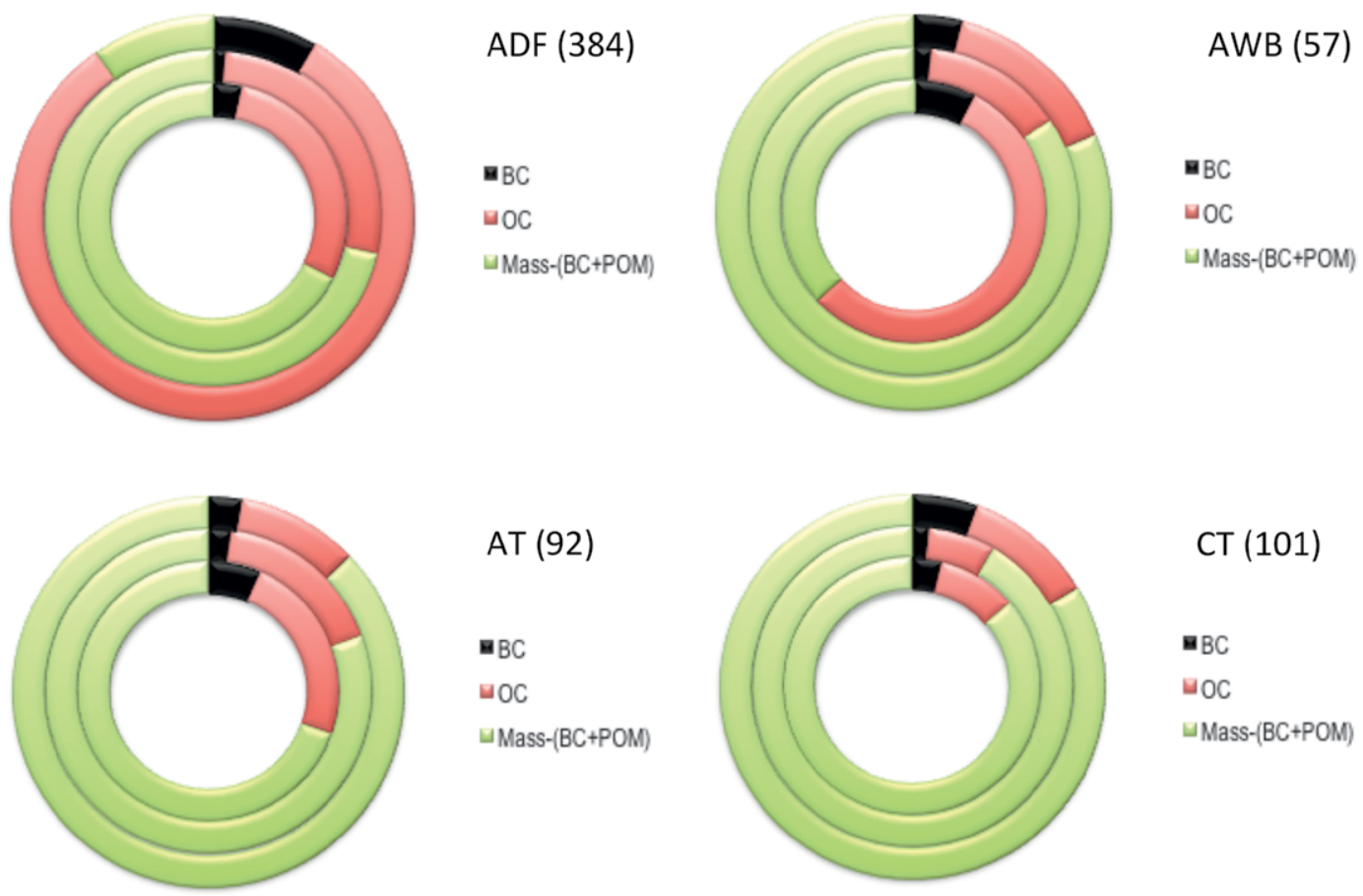

CT (101)

$\mathbf{B C}$

$\square \mathrm{OC}$

$\square$ Mass-(BC+POM)

FIG. 5. Aerosol composition (black carbon: BC; organic carbon: OC; particulate organic matter: POM) in Abidjan domestic fire site (ADF), Abidjan waste burning site (AWB), Abidjan traffic site (AT), and Cotonou traffic site (CT). The inner, middle, and outer circles indicate ultra-fine $(<0.2 \mu \mathrm{m})$, fine $(0.2-I \mu \mathrm{m})$, and coarse $(>\mathrm{I} \mu \mathrm{m})$ particles, respectively. Total aerosol mass $\left(\mu \mathrm{g} \mathrm{m}^{-3}\right)$ is given in parentheses.

Lamto, some $150 \mathrm{~km}$ inland of Abidjan. As a consequence, three coastal and three near-coastal stations were active (Figs. ES5 and ES6), resulting in an unprecedented sampling of the strength and depth of the low-level monsoon inflow and the land-sea breeze. Capacity building efforts were undertaken at Lamto and Accra, where operations were mainly executed by a team of German and African students, with invaluable help of GMET and Lamto staff. Both stations made up to five soundings per day, with the additional 0900 UTC soundings occurring at the diurnal peak of cloudiness associated with low-level stratus (Van der Linden et al. 2015). Finally, 0600 UTC soundings were performed systematically in Kumasi and Savè as explained in the "Ground-based campaign" section. Launching statistics and radiosonde types can be inferred from Figs. ES4-ES6 and Table 2. Altogether, some 772 radiosondes were launched. In addition, TEMP and, if possible, high-resolution 1200 UTC sounding data for June-July 2016 were acquired for Nigerian operational stations indicated in yellow in Figs. ES4-ES6. Thanks to an excellent collaboration with the German Weather Service, e-mailed real-time transmissions of FM 35 TEMP Mobile messages to the GTS were made for Lamto, Kumasi, Accra, and Parakou. The subcontracted company and Agence pour la Sécurité de la Navigation Aérienne en
Afrique et à Madagascar (ASECNA) ensured real-time transmission of Cotonou and Abidjan whereas FM 94 BUFFR TEMP mobile messages from Savè were emailed to and ingested by Météo France numerical weather prediction models.

The high-resolution data will contribute significantly to assessing and monitoring the time evolution of wind-stability-humidity regimes that are related to certain types of convection. Figure 4 shows a time-height diagram of zonal wind speed and barbs for Parakou. A thunderstorm in the afternoon of 8 July 2016 was associated with high values of lowlevel shear between monsoonal southwesterlies and midlevel easterlies, whereas the nonthundery rainfall between 11 and 14 July 2016 occurred in a strong and relatively deep low-level westerly regime with low shear. It is reminiscent of monsoon or vortex rainfall as discussed in Fink et al. (2006).

URBAN CAMPAIGN. The urban campaign was conducted on four sites representative of the main combustion sources specific to SWA (traffic, domestic fire, and waste burning), three of which are located in Abidjan (Ivory Coast) and one in Cotonou (Benin) (Fig. 2). The urban campaign took place on 4-10 July (Abidjan) and 10-13 July 2016 (Cotonou). The instrumented four sites are as follows: 

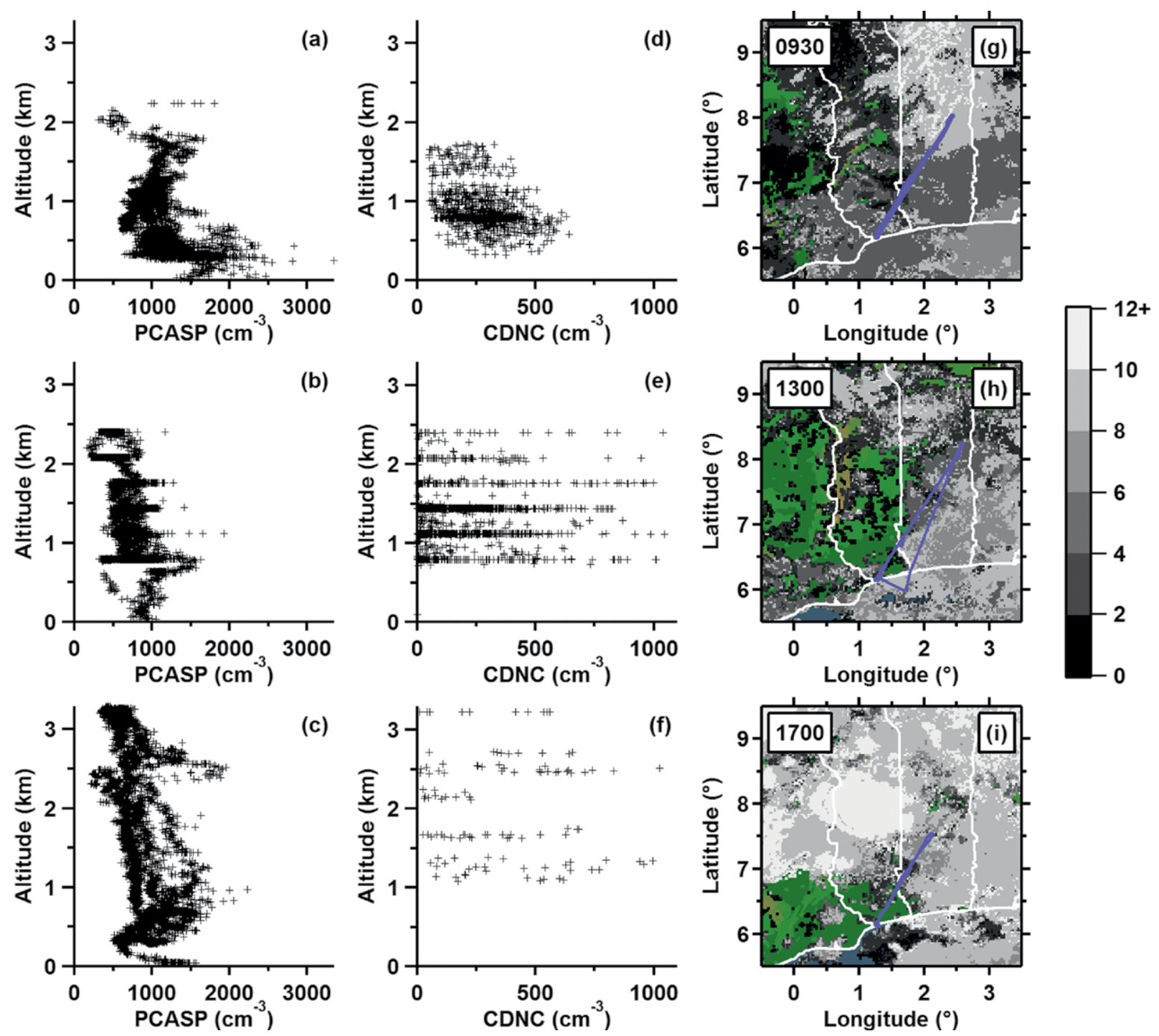

Fig. 6. Profiles of the aerosol concentration measured by PCASP probes on (a) the SAFIRE ATR 42 between 0800 and II 00 UTC, (b) the DLR Falcon 20 between II 20 and I500 UTC, and (c) the BAS Twin Otter between 1600 and 1750 UTC 5 Jul 20I6. (d)-(f) As in (a)-(c), respectively, but for the cloud droplet number concentration (CDNC). (g)-(i) SEVIRI cloud-top height taken at times during each research flight (ATR 42, Falcon 20, and Twin Otter, respectively; see text for the times of the flights). Green areas represent cloud-free regions as seen with SEVIRI.

1) Yopougon (Abidjan): Within a courtyard surrounded by houses using domestic fires for cooking, where more than 20 women use woodfires for fish smoking.

2) Adjamé (Abidjan): On the roof of a pharmacy, above a large street with frequent traffic jams and close to a large crossroad.

3) Akouedo (Abidjan): On the roof of a building built on the biggest waste burning hill of the country in activity since 1965.

4) Dantokpa (Cotonou): In front of the biggest market of Benin, on the balcony of a building near a crossing with a high traffic density. This site is impacted by emissions from both four- and two-wheel vehicles using gasoline fuel, as opposed to Abidjan where mainly diesel four-wheel vehicles are in use.

These measurements are combined with modeling and satellite data, aiming to link emission sources, air pollution, and health impacts in terms of lung inflammation and diseases in SWA. The July 2016 urban campaign is part of a long-term effort that was initiated in December 2014 and ended in March 2017. The aim of the long-term campaign is to calculate in situ dose-response functions for each studied sources on these four sites based on air pollution 


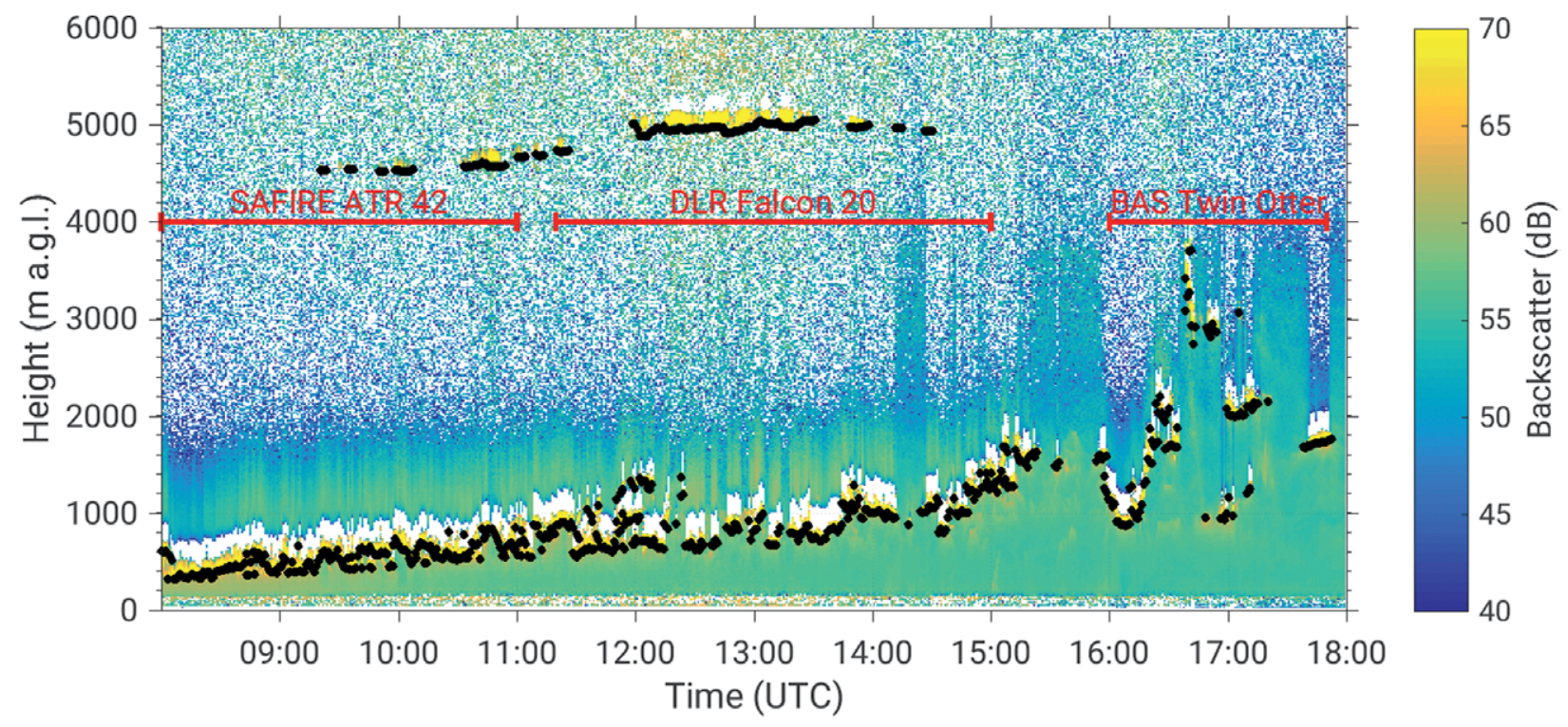

FIG. 7. Time-height evolution of backscatter (color coded) and cloud-base height from ceilometer (black dots) in Savè on 5 Jul 2016. Cloud bases are observed as the thin layer of high backscatter.

datasets and epidemiological surveys. The details of the measurements strategy are given in Table ES11.

The specific aims of the short-term July 2016 urban campaign are as follows:

1) To calculate in situ dose-inflammatory response ratios for each studied sources on the four sites. Doses in the respiratory tracts are obtained from atmospheric concentrations using a model. Air pollution experiments include three impactors running in parallel three times in each campaign in the same conditions, in order to determine aerosol chemical composition and their pro-oxidant capacity by size, as well as in vitro inflammatory biomarkers to derive inflammatory response. As an example for July 2016, Fig. 5 shows the carbonaceous aerosol importance in the aerosol mass by size, with higher ratios in Abidjan than in Cotonou. The highest mass concentration is found for the domestic fire site.

2) To establish spatial distributions of gaseous components (e.g., $\mathrm{NO}_{2}, \mathrm{O}_{3}$ ) in Abidjan and Cotonou with multisite deployment of passive samplers.

3) To measure emission factors for gases and particles for the main African specific urban sources (domestic fires with different woods and charcoal, charcoal making, and many representative twoand four-wheel vehicles) in the streets but also in combustion chambers. This will lead to a revised emission inventory.

4) To assess personal exposures to $\mathrm{PM}_{2.5}$ and aerosol chemistry emitted from domestic fire emissions for housewives, waste-burning emissions for students, and motor vehicle emissions for drivers. Participants were equipped with personal impactors and followed for three consecutive days (night and day).

SATELLITE. Observing aerosols, clouds, and precipitation from space over the SWA region remains challenging. The prevailing clouds make it difficult to properly monitor aerosols owing to a lack of clear-sky conditions required for aerosol retrieval. For clouds, Hill et al. (2016) found large differences between satellite cloud products particularly in high-and low-level cloud fractions. Different satellite rainfall retrieval approaches can also be associated with contrasting cloud sensitivities (e.g., Tompkins and Adebiyi 2012). Although active remote sensors like radar and lidar have better capability to probe cloud vertical structures, quantifying cloud properties is problematic because lidar backscatter is quickly attenuated with increasing cloud optical depth and radar signals are contaminated by ground clutter. Additionally, field campaigns dedicated to marine stratocumulus have shown evidence of an aerosol effect on warm rain suppression (Van Zanten et al. 2005; Mann et al. 2014). While warm rain frequency may not be as high as convective precipitation frequency over SWA (Mülmenstädt et al. 2015), the amount of warm rain and its susceptibility to aerosol perturbation have not been quantitatively determined over SWA.

Measurements from the DACCIWA field campaign have provided invaluable information for 
a.)
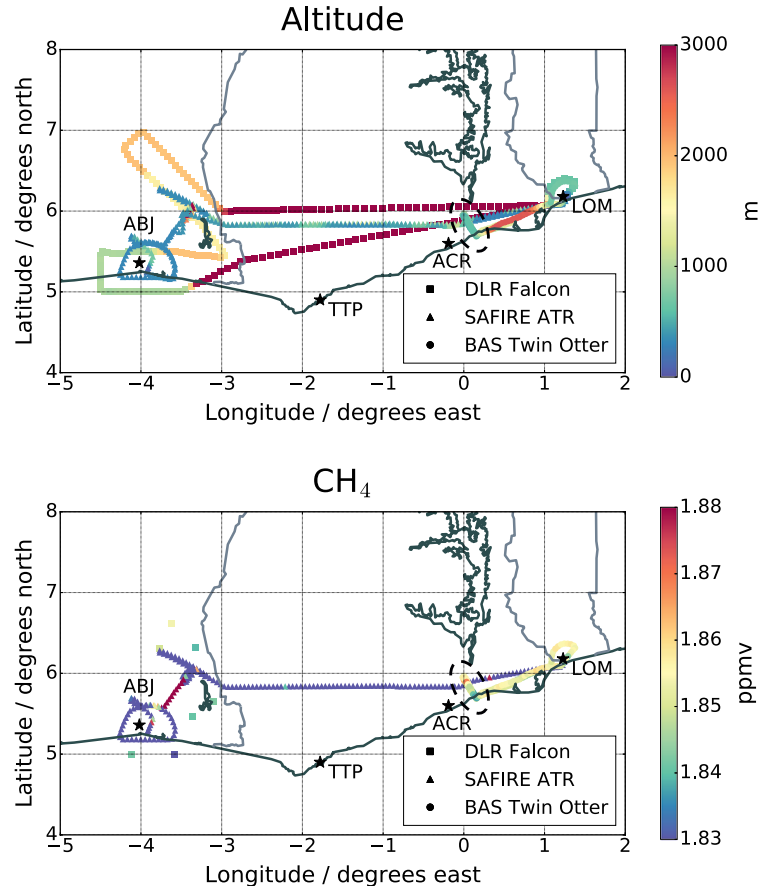

b.)

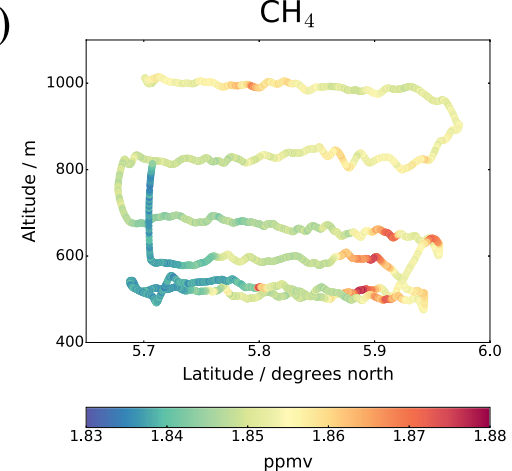

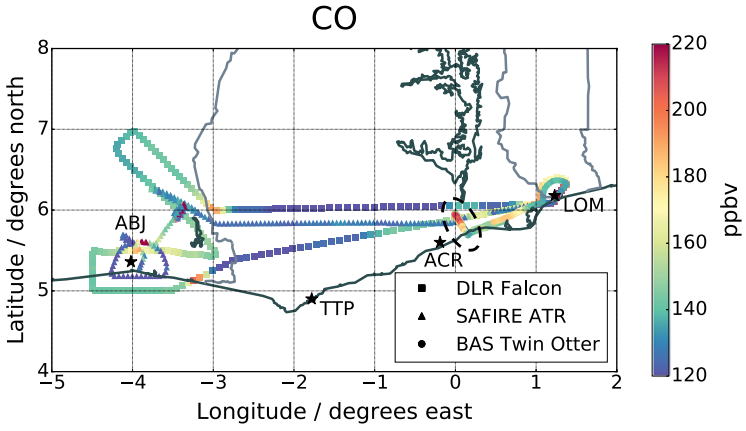

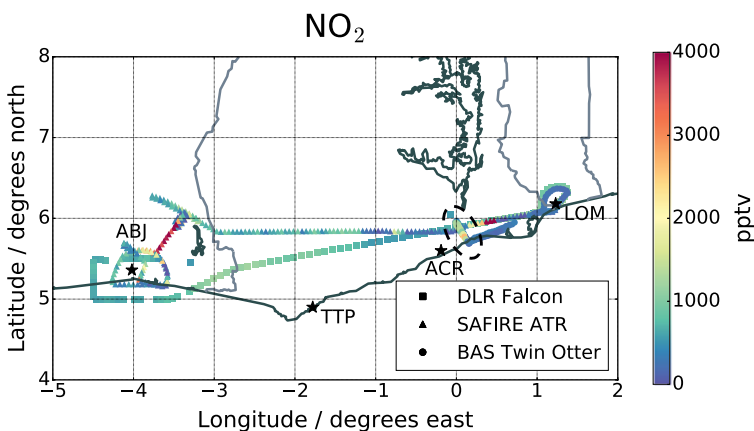

Longitude / degrees east

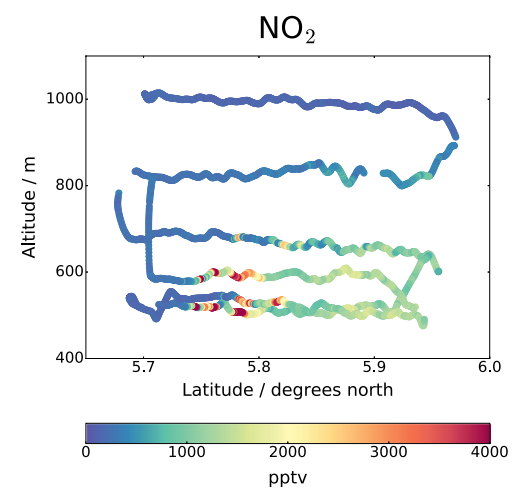

Fig. 8. (a) Flight tracks from the three aircraft for flights undertaken on $6 \mathrm{Jul} 2016$. Squares show the DLR Falcon, triangles the SAFIRE ATR, and circles the BAS Twin Otter. Points are colored by altitude $(\mathrm{m}), \mathrm{CO}(\mathrm{ppbv}), \mathrm{CH}_{4}$ (ppmv), and $\mathrm{NO}_{2}$ (pptv), all averaged for $60 \mathrm{~s}$ (except the $\mathrm{CH}_{4}$ data from the DLR Falcon, which are averaged over the 30-s bag sampling period). Also labeled are Abidjan, Ivory Coast (ABJ); Takoradi thermal power plant, Ghana (TTP); Accra, Ghana (ACR); and Lomé, Togo (LOM). (b) Cross sections of latitude vs altitude for the BAS Twin Otter legs downwind of Accra [from flight tracks within the black dashed line in (a)]. Data are I-s averaged.

evaluating satellite retrievals, such as cloud products from the Spinning Enhanced Visible and Infrared Imager (SEVIRI) aboard Meteosat, and a number of nongeostationary products, as shown in Fig. 1. We will evaluate satellite products in two ways. First, direct comparisons of cloud and aerosol statistics can be made by collocating satellite overpasses with aircraft transects and the instrumented ground sites. Second, using these satellite-based cloud and aerosol properties as input to radiative transfer models, we will perform radiation closure studies, comparing the calculated irradiances against the measurements. A total of eight flights were conducted for radiation closure studies (Table ES9), including two dedicated calibration flights, which are necessary for correcting shortwave downwelling radiation measurements affected by the aircraft pitch-and-roll offsets and the offset of the radiometers relative to the aircraft. Combining the airborne radiation measurements with those from ground sites and the Geostationary Earth Radiation Budget (GERB) instrument aboard Meteosat, the campaign provides an excellent opportunity to close the radiation budget at the surface, the aircraft altitude, and the top of the atmosphere, which is crucial for evaluating not only column-integrated properties of clouds and aerosols, but also their vertical structures and boundaries in satellite products. 


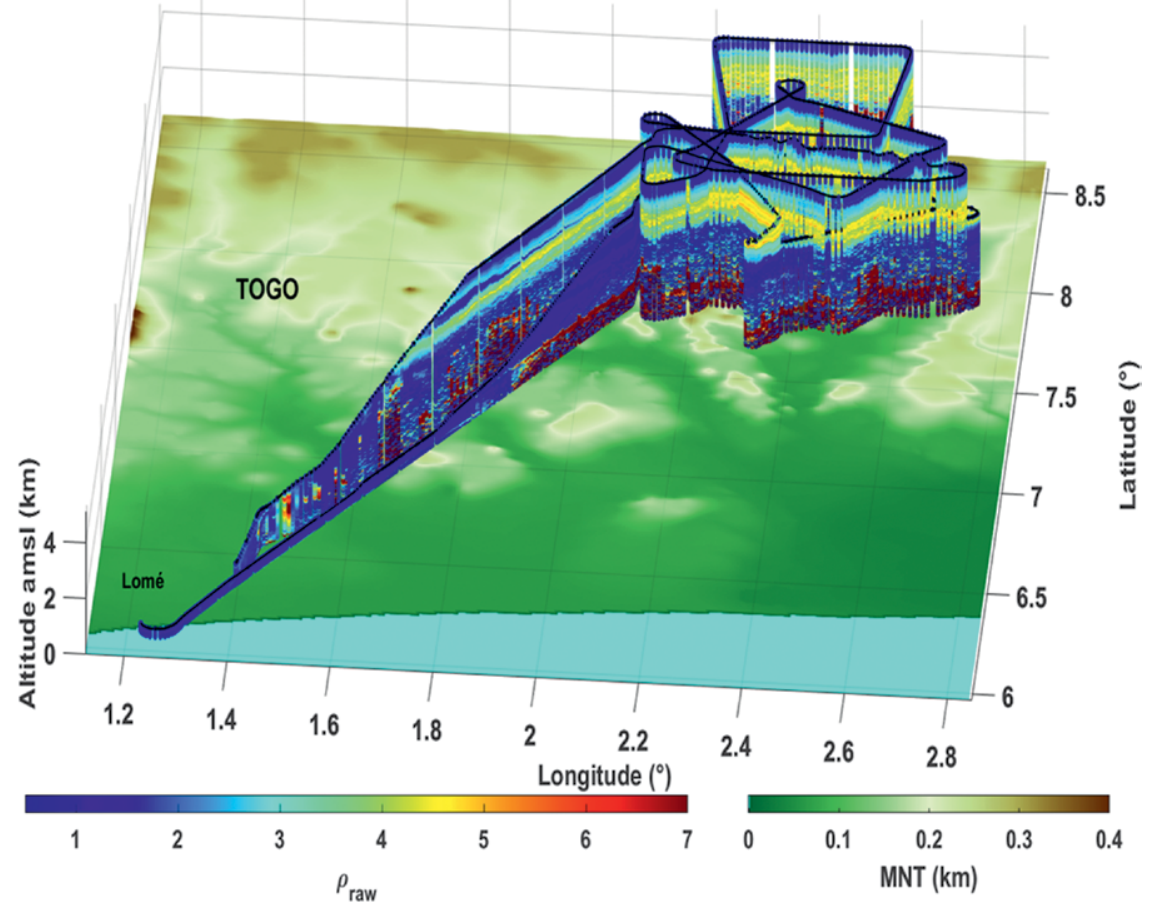

FIG. 9. Profiles of raw depolarization ratio $\rho_{\text {raw }}$ (color) measured from the Ultraviolet Lidar for Canopy Experiment (ULICE) lidar on board the SAFIRE ATR42 during flight 21 on 2 Jul 2016. The lidar data are overlain on terrain elevation (greenish colors). This figure is credited to $P$. Chazette (LSCE, CEA/CNRS).
42, DLR Falcon 20, and BAS Twin Otter flew on the same track from Lomé to Savè at different times of day (Table ES5). As discussed by Knippertz et al. (2017), the period of aircraft operations was characterized by a high fraction of low clouds (over 85\%).

The ATR 42 flew the Lomé-Savè track twice between 0800 and 1100 UTC (Fig. 6g), the Falcon 20 twice between 1120 and 1500 UTC (Fig. 6h), and the Twin Otter once between 1600 and 1750 UTC (Fig. 6i). This approach enabled investigation of the stratus-to-cumulus diurnal cycle, as well as concurrent changes in aerosol properties. All three aircraft were equipped with passive cavity aerosol spectrometer probes (PCASP; Figs. 6a-c)
CAMPAIGN HIGHLIGHTS. This section contains five examples of campaign observations. While preliminary, they illustrate the enormously rich data resource obtained in June and July 2016 and its potential to solve some long-standing scientific questions in the area of interactions between atmospheric composition and meteorology over SWA. The first example illustrates how the three aircraft worked together and in liaison with the Savè supersite to characterize the diurnal cycle of low-level clouds over Benin. The second example illustrates the aircraft strategy designed to sample emissions around and downstream of two big cities. The third example highlights how airborne radiation measurements will be used to investigate the quality of the spaceborne radiative products. The fourth example demonstrates the value of having a network of well-instrumented supersites to simultaneously characterize the LLC evolution across SWA. The last example provides insights into the structure and composition of a massive BB plume, unexpectedly sampled by two of the aircraft during cloud-oriented missions.

Diurnal evolution of cloud-aerosol interactions on 5 July 2016. On 5 July 2016, the three aircraft SAFIRE ATR to measure aerosol concentration in the range $0.125-3 \mu \mathrm{m}$. Cloud droplet number concentration (CDNC) profiles in Figs. 6d-f are from different types of instruments: a fast cloud droplet probe (CDP) for the ATR 42, a CDP for the Twin Otter, and a cloud and aerosol spectrometer (CAS) for the Falcon in the size range of 3-50 $\mu \mathrm{m}$ (see Tables ES2-ES4). Data from the entire flights are shown in Figs. 6a-f.

Pollution was ubiquitous throughout the lower few kilometers of the atmosphere (Figs. $6 \mathrm{a}-\mathrm{c}$ ). In the morning, a two-layer structure was observed below $2 \mathrm{~km}$ MSL with a marked maximum in the developing CBL, below $500 \mathrm{~m} \mathrm{MSL}$, and with evidence that the aircraft passed through plumes of increased aerosol concentrations, likely related to coastal cities upstream (Fig. 6a). During the ATR flight, large CDNC values (in excess of $500 \mathrm{~cm}^{-3}$ ) were measured near the top of the CBL, indicative of the polluted conditions affecting the clouds (Fig. 6d). Between 0800 and 0930 UTC, cloud tops remained below $1 \mathrm{~km}$ and cloud cover was higher at the northern end of the leg. In the vicinity of Savè, the stratocumulus base rose from 300 to $500 \mathrm{~m}$ AGL during the time of the ATR flight (Fig. 7). Throughout the late morning and afternoon, the low cloud deck became more broken and sparse (Figs. 6e,f), with some developing into 

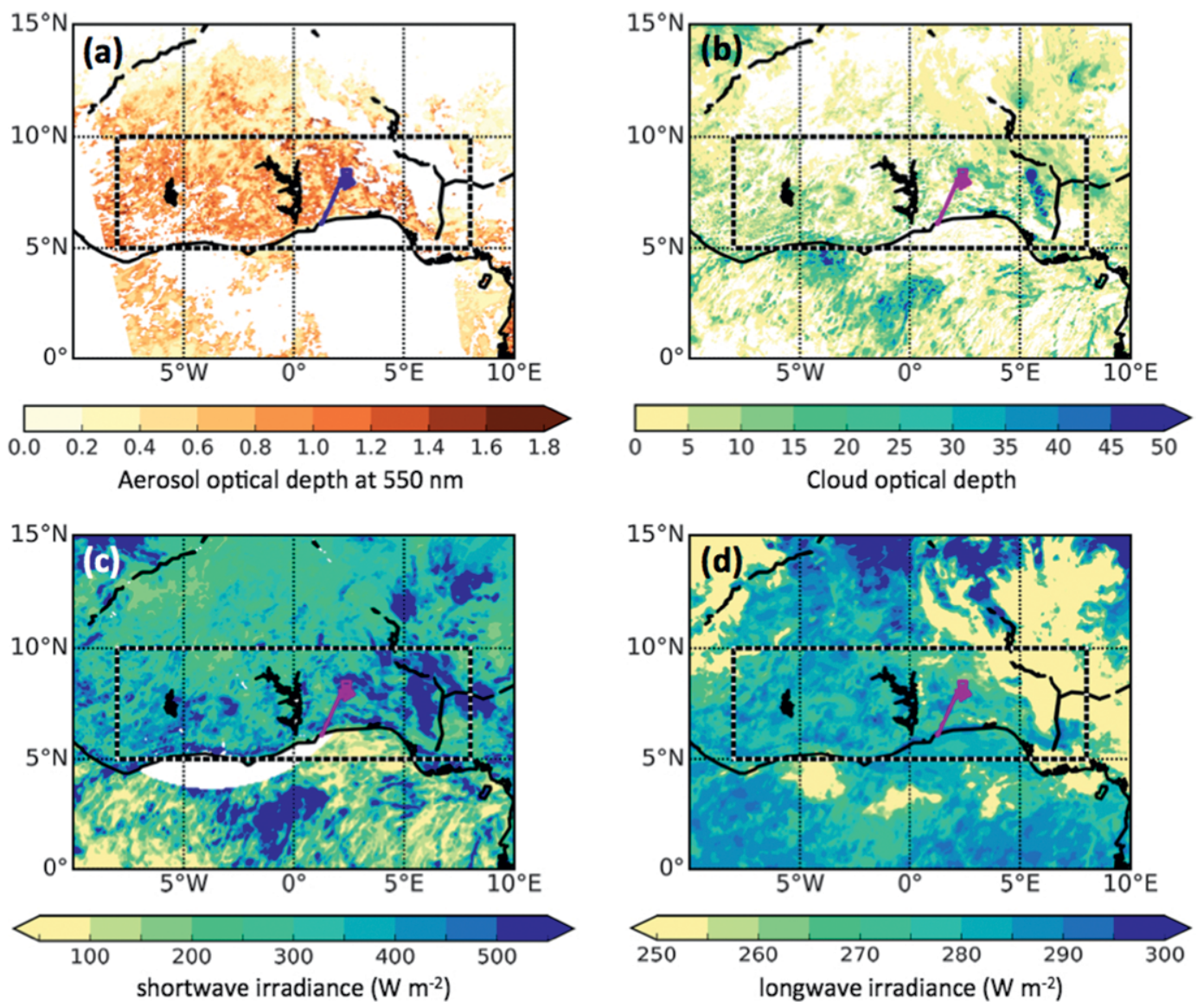

FIG. I0. (a) Aerosol optical depth at $550 \mathrm{~nm}$ retrieved from Suomi NPP overpass at I300 UTC. Note that aerosols over bright surfaces are not available yet in the current operational product. (b) Cloud optical depth and (c) SW and (d) LW irradiance at the top of the atmosphere observed from SEVIRI at I230 UTC. These are satellite observations close to the end of the flight track shown in Fig. 9. The ATR 42 flight track is shown as the purple solid line in all four panels. The DACCIWA focus region is indicated by a thick dashed box.

small cumuli with cloud tops growing to altitudes above $3 \mathrm{~km}$ MSL in the late afternoon (Fig. 6f). As observed in Savè, the cloud base reached $\sim 3,000 \mathrm{~m}$ AGL ( 3,160 m MSL) around 1700 UTC (Fig. 7). The high CDNC values observed in the morning flight in the lowest kilometer of the atmosphere were observed at higher altitudes in the late morning and afternoon. Aerosol concentrations were observed to be mixed over greater depths than in the morning, owing to the development of the CBL (Figs. 6b,c). The large spread of aerosol concentrations observed during the afternoon flights for a given altitude reflects the fact that the aircraft flew in and out of the urban plumes of Lomé and Cotonou.

Once fully validated and intercompared, measurements made on this day with the three aircraft (and other "cloud-aerosol interaction" flights; Tables ES8) will be used to investigate the effects of the lower-tropospheric dynamics/thermodynamics, as well as the direct and indirect effects of natural and anthropogenic aerosols, on the diurnal cycle of low cloud over different parts of SWA, and their representation in state-of-the-art models.

Urban emission mapping on 6 July 2016. On 6 July 2016, the three aircraft conducted coordinated flights across coastal SWA (Table ES5) to sample the outflow from the cities of Abidjan, Accra, and the Takoradi thermal power plant (see Fig. 8 for location). The ATR 42 was in the air between 0709 and 1502 UTC and refueled in Abidjan, while the Falcon 20 conducted one flight from 0941 to 1313 UTC. The end of the morning ATR flight, the beginning of the afternoon ATR flight, and the middle part of the Falcon flight were dedicated to exploring the Abidjan urban plume at various distances downstream of the city center, below $1 \mathrm{~km}$ MSL. The Twin Otter flight took place between 1355 and 1637 UTC and was focused on Accra city emissions. During the postonset period, strong pollution dispersion toward the northeast 

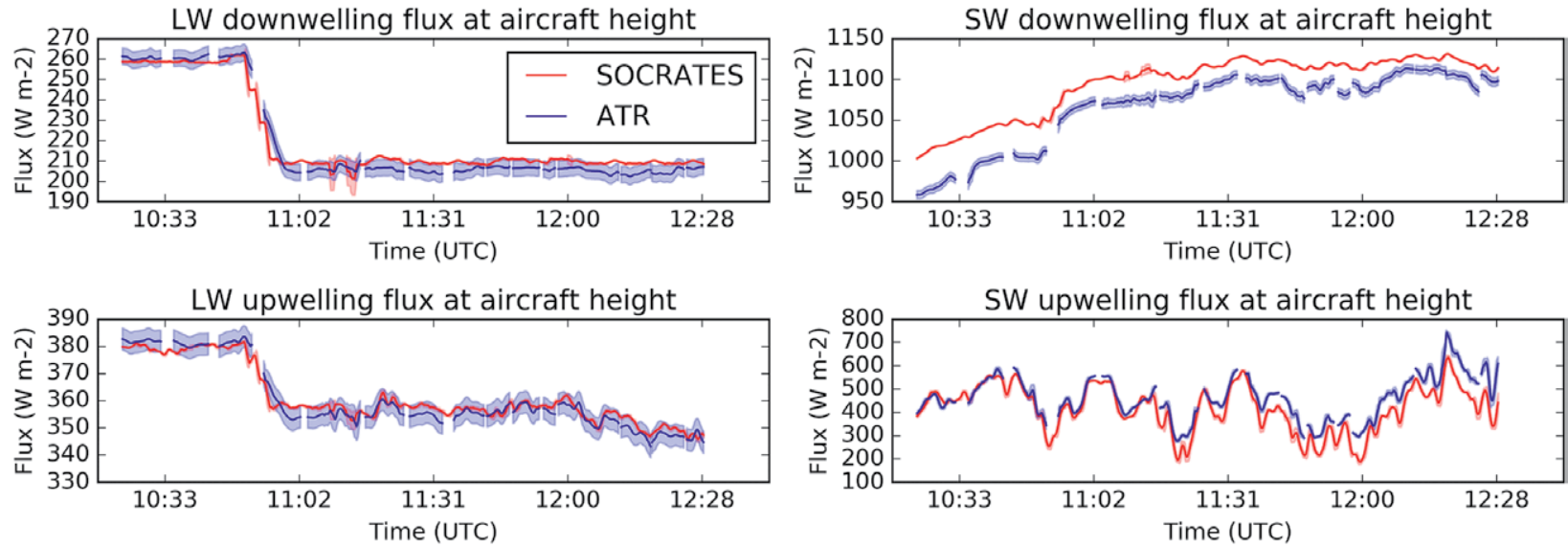

FIG. II. Intercomparison between the observed (blue) and the calculated (red; see text for details) (top) downwelling and (bottom) upwelling irradiances in the (left) LW and (right) SW spectral regions at the aircraft altitude during the ATR flight on 2 Jul 2016. Observed irradiances are shown with uncertainty of plus and minus one standard deviation in light blue shading, estimated from instrumental uncertainty. For SW downwelling irradiances, uncertainty also includes errors in correcting effects of aircraft pitch-and-roll offsets and radiometer mounting offsets. The associated uncertainty of plus and minus one standard deviation in light red shading accounts for temporal and spatial variations in satellite cloud retrievals.

was observed from coastal cities as pointed out by Knippertz et al. (2017).

Figure 8a shows tracks from the three aircraft colored by altitude, $\mathrm{NO}_{2}$ (indicative of high temperature combustion), carbon monoxide (CO; indicative of low-temperature combustion), and $\mathrm{CH}_{4}$ (which has both an anthropogenic and a natural component). Low-level wind direction across the flight region was generally from a southwesterly direction. From all three aircraft, enhanced levels of the three pollutants can be seen immediately downwind of the sources, with the DLR Falcon 20 and SAFIRE ATR 42 also sampling the Abidjan and Accra plumes up to $80 \mathrm{~km}$ farther west. Figure $8 \mathrm{~b}$ shows altitude-latitude cross sections of the outflow from Accra sampled by the BAS Twin Otter. Enhancements can be clearly seen for $\mathrm{NO}_{2}$ ( $<5$ ppbv), $\mathrm{CO}(100 \mathrm{ppbv})$, and $\mathrm{CH}_{4}(40 \mathrm{ppbv})$ and occur at different points along the transects, suggesting sources from different parts of the city (e.g., industrial versus residential areas). The plots also show the vertical distribution of the plume, which-combined with an assessment of the boundary layer height and measurements made upwind of the city-will enable a calculation of the emission rate of $\mathrm{NO}_{2}, \mathrm{CO}$, and $\mathrm{CH}_{4}$ from Accra.

The observations acquired on this and other "city emission" flights (Tables ES6) will be used to constrain emissions in dedicated atmospheric chemistry models and apportion the relative importance of the main anthropogenic emissions contributing to air quality degradation in and downstream of major coastal cities in SWA.
Dust outbreak and implications for radiation on 2 July 2016. On 2 July 2016, the ATR performed a calibration flight from 0940 to 1300 UTC that contained several transects from a rotating box pattern (see Fig. 9), aiming to collect measurements at various relative azimuth angles to the sun. In principle, calibration flights require clear, clean-sky conditions above the aircraft, which was a challenging requirement to meet over SWA. As shown in Fig. 9, the polarization ratio profiles measured by the ATR lidar indicated an aerosol layer at $4 \mathrm{~km}$ MSL, which was also spotted by pilots and detected with in situ aerosol measurements.

The presence of the thick aerosol layer led to the decision to climb after completing the first box pattern. However, toward the end of the flight, frequent clouds and aerosol were present over SWA (Fig. 10), making both calibration and radiation closure studies challenging. During the aircraft campaign, dust was forecasted by the European Centre for Medium-Range Weather Forecasts (ECMWF) Copernicus Atmosphere Monitoring Service-Integrated Forecasting System to be mainly north of $8^{\circ} \mathrm{N}$ (latitude of Savè) and southward transport over the Soudanian zone was clearly modulated by major synoptic-scale features (Knippertz et al. 2017).

Figure 11 shows an example of a radiation closure at the aircraft altitude, using calibrated upwelling and downwelling irradiances in the shortwave (SW) and longwave (LW) spectral regions from the flight in Fig. 9. We compare measured irradiances with those calculated from radiative transfer, using atmospheric profiles from ECMWF interim reanalysis 
a)

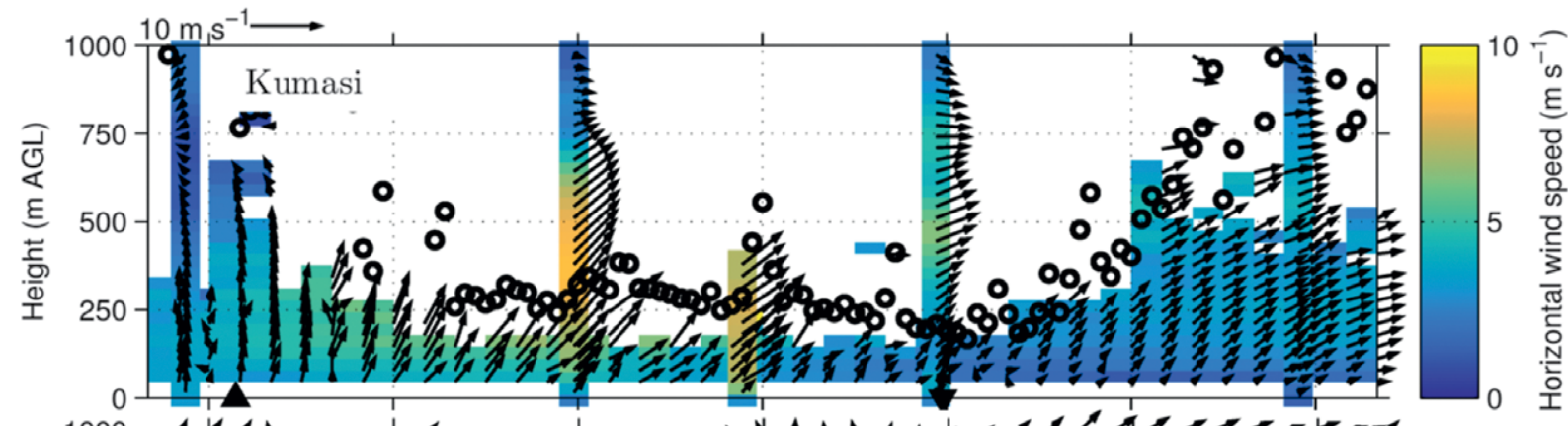

b)
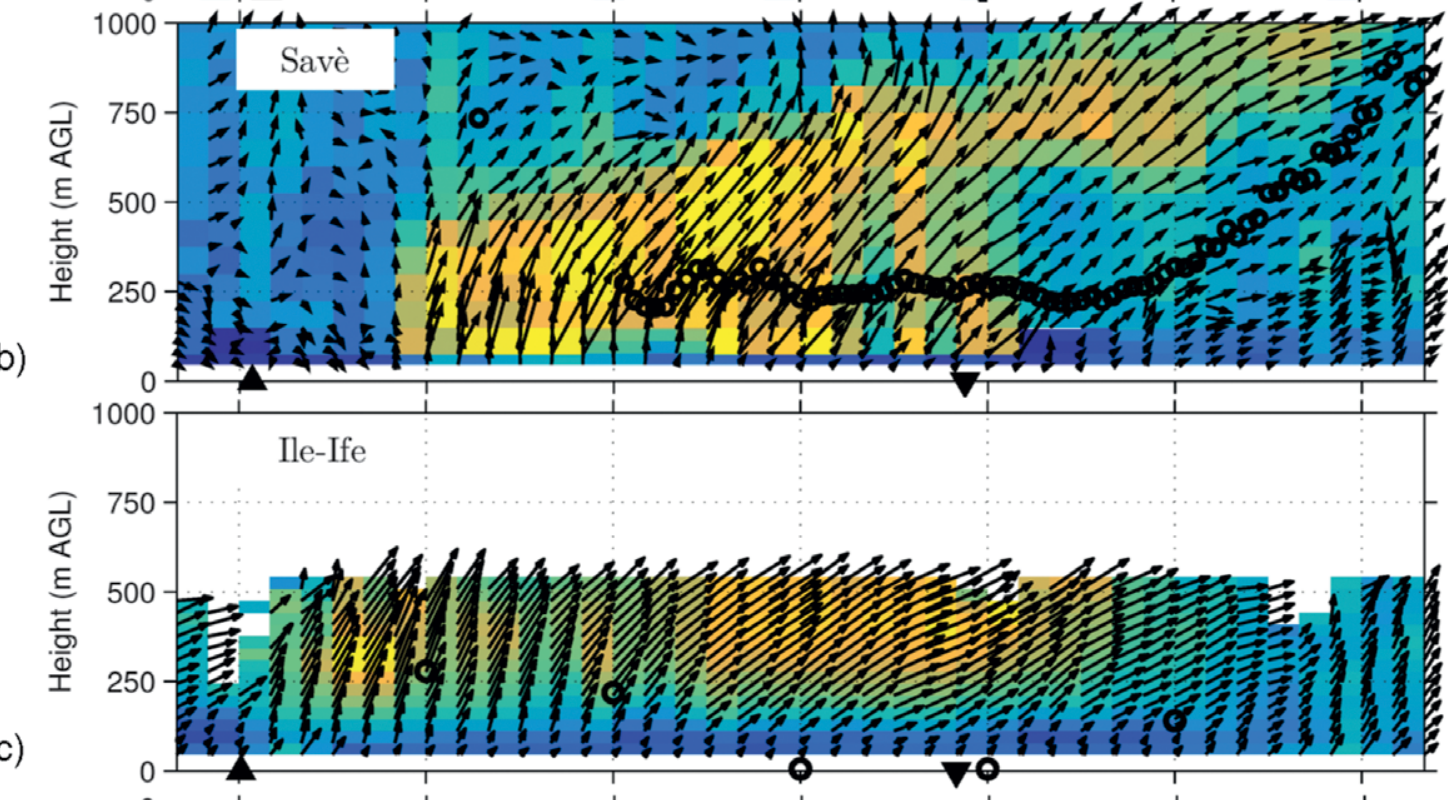

c)

d)

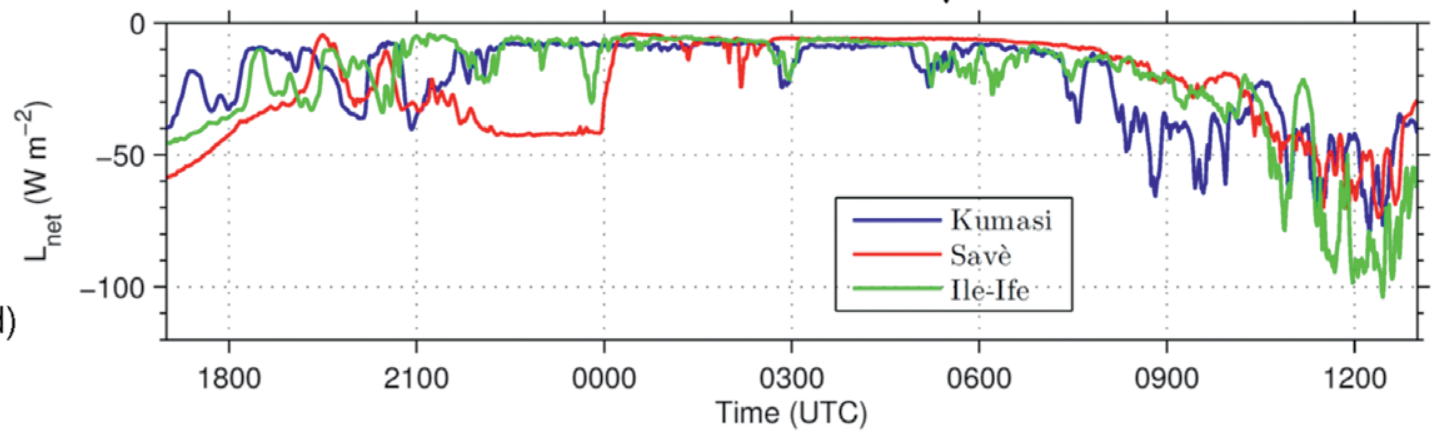

Fig. 12. (a)-(c) Horizontal wind vectors (arrows), absolute value of wind speed (color coded), and cloud base (circles) for the three ground sites at Kumasi, Savè, and Ile-Ife, and (d) I-min-averaged net longwave radiation. The up and down triangles in (a)-(c) indicate sunset and sunrise, respectively. In Kumasi the wind is derived from radiosondes and sodar, in Savè it is a composite of sodar and UHF wind profiler data, and in lle-Ife it is based on sodar data. The cloud-base height for Kumasi and Savè is derived from ceilometer data and is based on the algorithm of the manufacturers. For Ile-Ife, the cloud-base height is estimated from the relative humidity data measured with tethered radiosondes.

(ERA-Interim) and cloud properties from SEVIRI as input. Irradiances were calculated using the Suite of Community Radiative Transfer Codes Based on Edwards and Slingo (SOCRATES; Edwards and Slingo 1996). Overall, the agreement between measured and calculated irradiances appears reasonable for the LW, but there are clear discrepancies in the SW. The calculated downwelling irradiance is systematically larger than the measurements, which may be due to overlying aerosol layers that have not been included in radiative transfer calculations. In the upwelling direction, the calculated SW irradiance agrees with the measurements reasonably well in the first part of the aircraft transect, but tends to be $50 \mathrm{~W} \mathrm{~m}^{-2}$ smaller after 1105 UTC, suggesting that clouds from SEVIRI retrievals are not bright enough. These hypothesized 


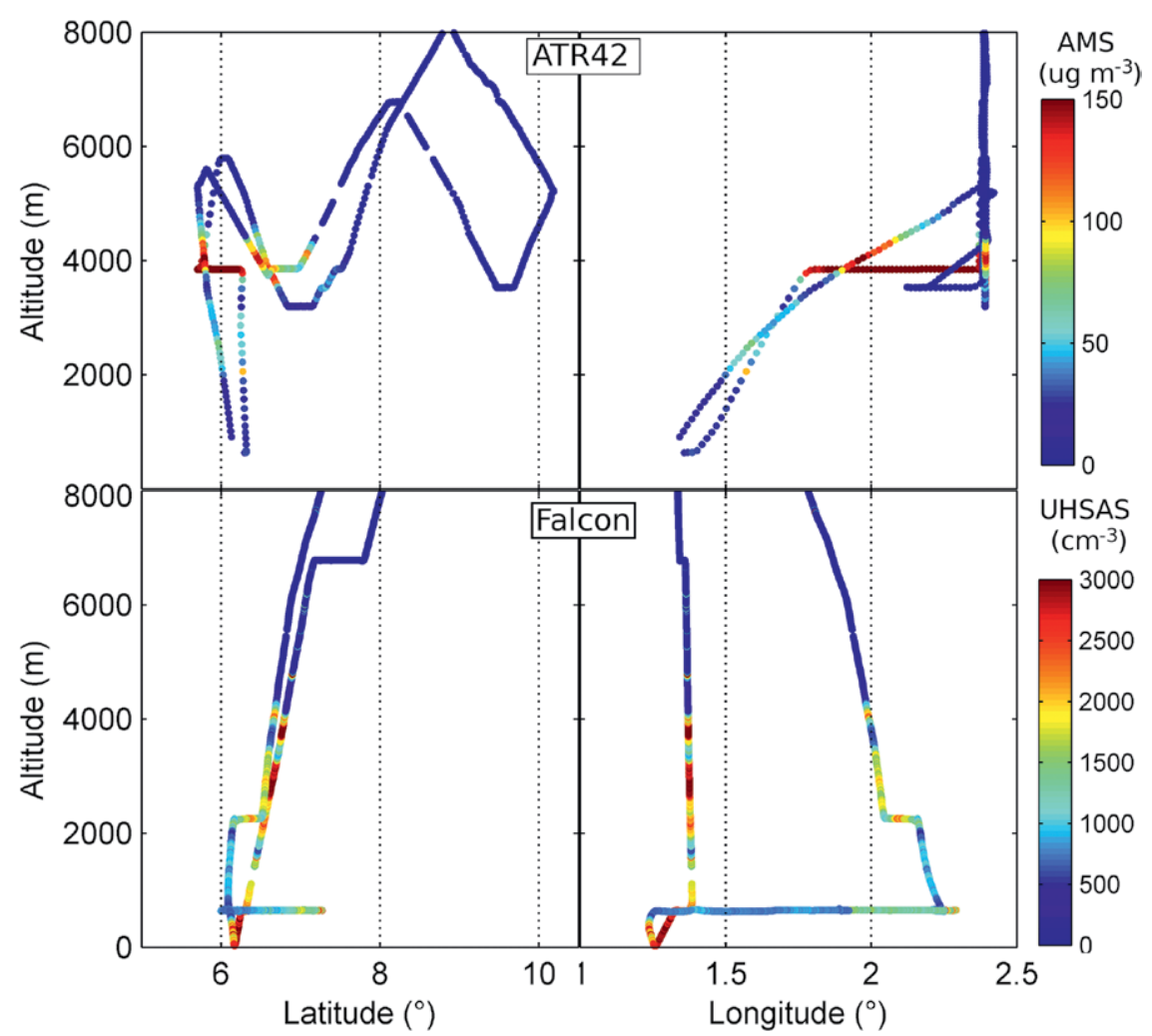

FIG. 13. (left) Latitude-altitude representation of the (top) ATR 42 and (bottom) Falcon 20 flight tracks on 13 Jul 2016. (right) Longitude-altitude representation of the (top) ATR 42 and (bottom) Falcon 20 flight tracks. The ATR flight track is color coded according to AMS-derived NR-PMI concentrations and the Falcon flight track is color coded according to UHSAS-derived aerosol concentrations. See text in "BB aerosol plume on 13 Jul 2016" section for details.

sources of errors will be investigated further using cloud and aerosol properties from the aircraft and ground sites and the GERB instrument (as shown in Fig. 10 and described in the "Satellite" section).

Low-level clouds on 7-8 July 2016. To demonstrate the spatiotemporal evolution of nocturnal LLCs and their relation to the horizontal wind field, we select an IOP in which nocturnal LLCs develop at all three supersites (IOP 8; 7-8 July 2016). On this day, the large-scale conditions in the investigation area are characterized by about 1,000-m-deep southwesterly monsoon flow and the AEJ above, as evident from the radiosonde network data (see "Radiosonde campaign" section; Fig. 4). During the afternoon of 7 July, a moderate monsoon flow of about $3 \mathrm{~m} \mathrm{~s}^{-1}$ prevails. The transition layer from the southwesterly monsoon flow to the easterly wind above ranges from about 1,000 to $1,500 \mathrm{~m}$ AGL. The wind speed of the AEJ increases from south to north; for example, the UHF wind profiler at Savè detects the AEJ at about $3,500 \mathrm{~m}$ AGL with $15 \mathrm{~m} \mathrm{~s}^{-1}$ winds.
The comparison of the occurrence and base height of the LLCs at the three supersites reveals a considerable variability (Fig. 12). In Ile-Ife, the first LLCs were observed around 2100 UTC (Fig. 12c). In Kumasi, the first LLCs are detected at 2030 UTC, becoming continuous after 2130 UTC (Fig. 12a). In Savè, the LLCs developed around midnight (Fig. 12b). During the night, the cloud base at IleIfe drops from $300 \mathrm{~m}$ AGL at 2100 UTC to around $30 \mathrm{~m} \mathrm{AGL}$ at 0300 UTC. At Savè, the cloud base is rather constant at about $250 \mathrm{~m}$ AGL. At Kumasi the cloud base decreases slightly from about $300 \mathrm{~m}$ AGL at 2200 UTC to $200 \mathrm{~m}$ AGL in the early morning. The ceilometer data from Kumasi and Savè show that the cloud base starts to rise between 0700 and 0800 UTC (Figs. 12a,b). The cloud base starts to rise when the net radiation becomes positive, as seen in energy balance data (not shown). At 1200 UTC, when the CBL is well established, the cloud base is at about $700 \mathrm{~m}$ AGL at Kumasi and at $800 \mathrm{~m}$ AGL at Savè.

The different evolution of LLCs at the three supersites is also reflected in the net LW radiation, $L_{\text {net }}=L \downarrow-L \uparrow(L \downarrow$ denotes the downward and $L \uparrow$ the upward LW radiation; Fig. 12d). LLC are accompanied by an increase of the $L_{\text {net }}$ to a value of about $-10 \mathrm{~W} \mathrm{~m}^{-2}$. For example, the formation of LLCs at Savè shortly after midnight (Fig. 12b) results in an abrupt increase of $L_{\text {net }}$ from about -40 to $-10 \mathrm{~W} \mathrm{~m}^{-2}$ (Fig. 12d). The strong temporal changes of $L_{\text {net }}$ in the morning (between 0800 and 1000 UTC) suggest that the clouds are more broken at Kumasi than at Savè and Ile-Ife.

Figure 12 also includes information about the horizontal wind field. A nocturnal southwesterly LLJ forms at all three sites. Schrage and Fink (2012) pointed to the important contribution of LLJs on LLC formation. While the maximum wind speed is rather similar at all sites (around $8-10 \mathrm{~m} \mathrm{~s}^{-1}$ ), considerable differences occur in its onset time and 
duration. At Ile-Ife, an LLJ forms after 1900 UTC and is more or less continuous until around 0800 UTC (Fig. 12c). The LLJ at Savè forms $2 \mathrm{~h}$ later (i.e., at 2100 UTC) and becomes deeper in the course of the night (Fig. 12b). In Kumasi, a distinct LLJ exists at midnight and 0300 UTC and strongly weakens until 0600 UTC (Fig. 12a). At all sites, surface-based heating after sunrise causes vertical mixing and the dissolution of the LLJ. This process occurs parallel to the rise of the cloud base, as best seen at Savè (Fig. 12b).

The comprehensive dataset will be used for analysis of statistics for the whole period as well as investigating individual cases with and without LLCs to identify processes relevant to the diurnal cycle of LLCs and to study the impact of LLC on the CBL conditions.

BB aerosol plume on 13 July 2016. The postonset period was most favorable to the observation of BB aerosol plumes from the Southern Hemisphere over the DACCIWA region (Knippertz et al. 2017). On 13 July 2016, an anticyclonic vortex traveling over the Gulf of Guinea led to the transport of a massive BB plume originating from central Africa. The Falcon 20 and ATR 42 conducted flights in the morning (0918-1242 UTC) and afternoon (1225-1551 UTC), respectively, which enabled sampling the aged BB plume at different times and in different locations (Fig. 13). During these flights, the instruments observed the highest $\mathrm{CO}$ and organic aerosol concentrations as well as aerosol extinction coefficient values of the entire aircraft detachment period.

Figure 14 shows the vertical profile of aerosol number concentration and submicron nonrefractory aerosol mass concentration (NR-PM $)_{1}$ acquired on board both the ATR and the Falcon. The NR-PM measured by the aerosol mass spectrometers (AMSs) on both aircraft shows a significant enhancement between 1.5 and $4.5 \mathrm{~km} \mathrm{MSL}$, indicative of the presence of a BB plume. The Falcon-observed profile shows a single layer, while the ATR-observed profiles exhibit a two-layer structure with NR-PM 1 values peaking at $40 \mu \mathrm{g} \mathrm{m}^{-3}$ at $2.5 \mathrm{~km}$ MSL and nearly $100 \mu \mathrm{g} \mathrm{m}^{-3}$ at $3.8 \mathrm{~km}$ MSL (the former AMS is still undergoing calibration such that values in Fig. 14 are in arbitrary units). Unexpectedly, high values of NR-PM concentrations $\left(\sim 20 \mu \mathrm{g} \mathrm{m}^{-3}\right)$ were observed above the top of the marine boundary layer. The differences may be related to the fact that the aircraft did not sample the plume in the exact same location, with the ATR 42 


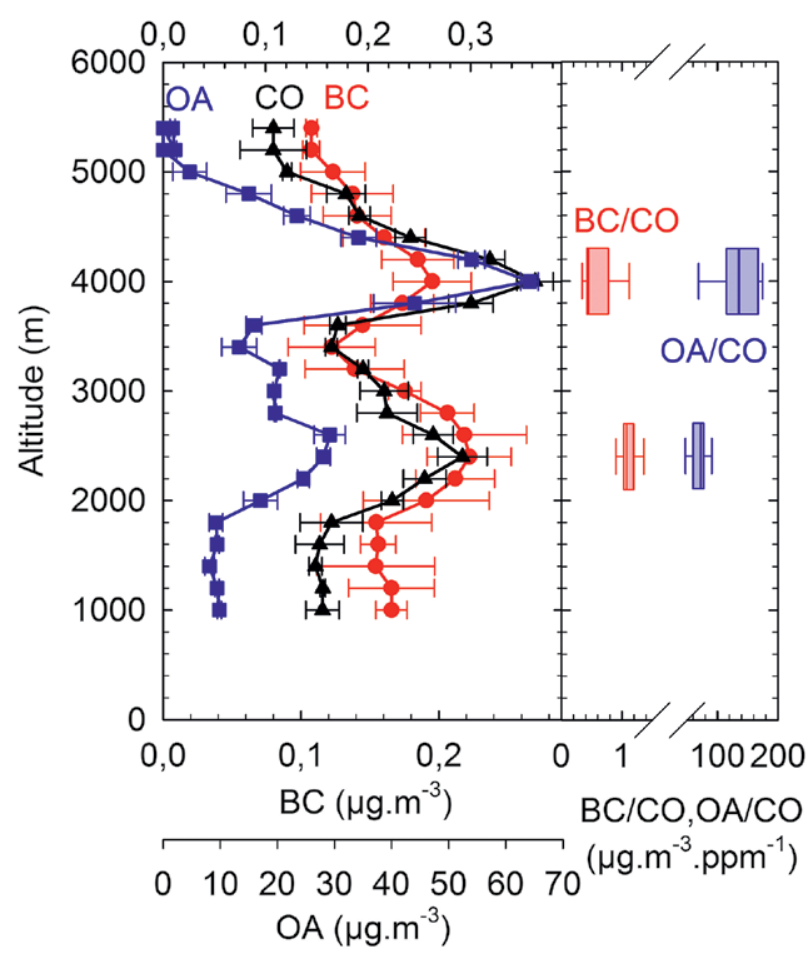

FIG. I5. Vertical profile of (left) BC, OA, and CO and (right) the $\mathrm{BC} / \mathrm{CO}$ and $\mathrm{OA} / \mathrm{CO}$ ratios derived from these measurements. The points are mean concentration at each level and the bars through them are the standard errors.

operating farther to the west (see Fig. 13), or to the temporal evolution of the BB plume.

Aerosol number concentration was measured on board the Falcon using a condensation particle counter (CPC) and an ultra-high-sensitivity aerosol spectrometer (UHSAS), measuring particles with a diameter larger than 10 and $100 \mathrm{~nm}$, respectively. The enhanced concentrations observed between 2 and $4 \mathrm{~km}$ MSL with the CPC and the UHSAS (collocated with the AMS) and the agreement between the two instruments are an indication that the aerosol population is strongly dominated by the accumulation mode, in good agreement with previous measurements of $\mathrm{BB}$ aerosols (e.g., Brito et al. 2014). Refractory black carbon (rBC) measurements, performed using the Single Particle Soot Photometer (SP2) on board the ATR 42, provide further insight into the chemical composition of BB plumes at different altitudes. The $\mathrm{rBC}$ profile reveals two concentration maxima in biomass burning layers, concurrently with enhanced concentrations of organic aerosols $(\mathrm{OA})$ and $\mathrm{CO}$ (Fig. 15). Interestingly, higher concentrations of both $\mathrm{OA}$ and $\mathrm{CO}$ were observed in the upper plume around 4 $\mathrm{km} \mathrm{MSL}$, while $\mathrm{rBC}$ concentrations were similar in both layers. Since forest fires are important emission sources for $\mathrm{OA}, \mathrm{CO}$, and $\mathrm{rBC}$, the contrast in $\mathrm{rBC} / \mathrm{OA}$ and $\mathrm{rBC} /$
$\mathrm{CO}$ ratios between the two $\mathrm{BB}$ layers likely relates to different processes affecting the air masses during their transport (e.g., Pan et al. 2011; Jolleys et al. 2015).

These observations have major implications for understanding the climatic effects of biomass burning aerosols, since the aging processes take place over large spatial and temporal scales. Future research specifically targeting aerosol microphysical and chemistry processes is therefore essential to understand the cause of this variability and provide reliable parameterizations of $\mathrm{BB}$ processes. In addition to providing a wealth of observations to validate and improve atmospheric chemistry models, the data from these flights will be used to assess the impact of long-range transport of $\mathrm{BB}$ aerosols on air quality in the DACCIWA region compared to city emissions. They will also serve to improve our understanding of the radiative impact of $\mathrm{BB}$ aerosols on the formation and life cycle of midlevel clouds, which was the primary objective of the MICWA operation conducted with the ATR on 13 July 2016.

CONCLUSIONS AND OUTLOOK. The DACCIWA project organized an ambitious field campaign over SWA (Ivory Coast, Ghana, Togo, Benin, and Nigeria) during June and July 2016, bringing together over 200 people from European and African institutions. The campaign included aircraft, groundbased, urban, and radiosounding components to improve our knowledge of the physical processes involved in the low-level cloud life cycle in the complex chemical environment of SWA and the implications for weather, climate, and air pollution. During this detachment, DACCIWA scientists conducted a total of 155 flight hours using three aircraft, acquired over $1,100 \mathrm{~h}$ of data from three ground supersites, and launched over 770 radiosondes. An unprecedented wealth of in situ and remote sensing observations was obtained over SWA using state-of-the-art instruments, which were implemented in a timely manner thanks to the genuine cooperation between European and African partners. Moreover, capacity building efforts were undertaken in Benin, Ghana, and Ivory Coast at several supersites and radiosonde stations.

A number of "firsts" were achieved during the DACCIWA field campaign:

1) documentation of the diurnal cycle of stratus, stratocumulus, and cumulus over SWA using three aircraft with very similar payloads measuring atmospheric dynamics/thermodynamics, gas-phase chemistry, aerosols, and clouds in coordination with a wide range of ground-based 
instrumentation and the densest radiosounding network ever;

2) systematic mapping of pollution around and downstream of Accra and Lomé plus some occasional measurements around Abidjan and Cotonou in coordination with surface-based urban emission measurements;

3) documentation of atmospheric dynamics/ thermodynamics and composition in the vicinity of midlevel clouds;

4) observations to link atmospheric conditions in the region of coastal upwelling with the life cycle of inland stratocumulus;

5) dedicated aircraft-based radiation calibration and closure effort to improve satellite-based radiation products specifically over SWA in a contrasted and complex chemical environment; and

6) seven weeks of continuous high-quality in situ and remote sensing measurements in SWA, invaluable for process studies and model evaluation.

Finally, observations acquired during the DACCIWA field campaign will undoubtedly contribute to improve climate, weather, and air-quality models as well as satellite retrievals, which are needed to support policies toward a more sustainable development for the region. This ambitious goal can hardly be achieved by researchers directly involved in the DACCIWA campaign alone. Therefore, all qualitychecked data, along with necessary meta information, will be made available in the DACCIWA database after a two-year embargo period (May 2019, at the latest) but are available for immediate use for associated partners. The DACCIWA database is hosted by the Base de l'Afrique: Beyond AMMA Base (BAOBAB) website (http://baobab.sedoo.fr), which allows accessing data from AMMA and several other West African field activities. The DACCIWA project has partly supported this website and it is hoped that this article contributes to a wide usage of its rich data content.

ACKNOWLEDGMENTS. The DACCIWA project has received funding from the European Union Seventh Framework Programme (FP7/2007-2013) under Grant Agreement 603502. The European Facility for Airborne Research (EUFAR; www.eufar.net/) also supported the project through the funding of three Transnational Activity projects: MICWA, APSOWA, and OLACTA (for additional details, see www.eufar.net/media/uploads/documents/filer _public/8a/93/8a93ecc5-c9b4-4536-8b9c-daa54lada8fc leufar_newsletter_sept2016_issuel7.pdf). The Centre National d'Etudes Spatiales (CNES) also provided financial support to the project. The authors are grateful to the numerous colleagues from European and African institutions that have contributed to the DACCIWA field campaign. We have listed them in the supplement to this overview paper. The Service des Avions Français Instrumentés pour la Recherche en Environnement (SAFIRE, a joint entity of CNRS, Météo-France, and CNES and operator of the ATR 42), the British Antarctic Survey (BAS, operator of the Twin Otter), and the Deutsches Zentrum für Luft- und Raumfahrt (operator of the Falcon 20) are thanked for their support. The authors would also like to thank Gregor Pante for help with producing Fig. 4. We are thankful to the anonymous referees and the editor for having taken the time to review the paper and make suggestions on how to improve it. This paper is dedicated to the memory of our friend and colleague Dr. Abdou Konaré, who played an important role in the preparation and accomplishment of the DACCIWA field campaign.

\section{REFERENCES}

Adler, B., N. Kalthoff, and L. Gantner, 2017: Nocturnal low-level clouds over southern West Africa analysed using high-resolution simulations. Atmos. Chem. Phys., 17, 899-910, 2017, https://doi.org/10.5194 /acp-17-899-2017.

Bourgeois, Q., A. M. L. Ekman, M. R. Igel, and R. Krejci, 2016: Ubiquity and impact of thin mid-level clouds in the tropics. Nat. Commun., 7, 12432, https://doi.org/10 .1038/ncomms12432.

Brito, J., and Coauthors, 2014: Ground-based aerosol characterization during the South American Biomass Burning Analysis (SAMBBA) field experiment. Atmos. Chem. Phys., 14, 122069-122083, https://doi .org/10.5194/acp-14-12069-2014.

Edwards, J. M., and A. Slingo, 1996: Studies with a flexible new radiation code. I: Choosing a configuration for a large-scale model. Quart. J. Roy. Meteor. Soc., 122, 689-720, https://doi.org/10.1002 /qj.49712253107.

Fink, A. H., D. G. Vincent, and V. Ermert, 2006: Rainfall types in the West African Sudanian zone during the summer monsoon 2002. Mon. Wea. Rev., 134, 2143-2164, https://doi.org/10.1175/MWR3182.1.

— - and Coauthors, 2011: Operational meteorology in West Africa: Observational networks, weather analysis and forecasting. Atmos. Sci. Lett., 12, 135-141, https://doi.org/10.1002/asl.324.

Gounou, A., F. Guichard, and F. Couvreux, 2012: Observations of diurnal cycles over a West African meridional transect : Pre-monsoon and full-monsoon Seasons. Bound.-Layer Meteor., 144, 329-357, https:// doi.org/10.1007/s10546-012-9723-8.

Hannak, L., P. Knippertz, A. H. Fink, A. Kniffka, and G. Pante, 2017: Why do global climate models 
struggle to represent low-level clouds in the West African summer monsoon? J. Climate, 30, 1665-1687, https://doi.org/10.1175/JCLI-D-16-0451.1.

Hill, P. G., R. P. Allan, J. C. Chiu, and T. H. M. Stein, 2016: A multisatellite climatology of clouds, radiation, and precipitation in southern West Africa and comparison to climate models. J. Geophys. Res. Atmos., 121, 102857-102879, https://doi .org/10.1002/2016JD025246.

IPCC, 2013: Climate Change 2013: The Physical Science Basis. Cambridge University Press, 1535 pp.

Jolleys, M. D., and Coauthors, 2015: Properties and evolution of biomass burning organic aerosol from Canadian boreal forest fires. Atmos. Chem. Phys., 15, 3077-3095, https://doi.org/10.5194/acp-15-3077 $-2015$.

Knippertz, P., and Coauthors, 2015a: The DACCIWA project: Dynamics-aerosol-chemistry-cloud interactions in West Africa. Bull. Amer. Meteor. Soc., 96, 1451-1460, https://doi.org/10.1175/BAMS -D-14-00108.1.

—, M. J. Evans, P. R. Field, A. H. Fink, C. Liousse, and J. H. Marsham, 2015b: The possible role of local air pollution in climate change in West Africa. Nat. Climate Change, 5, 815-822, https://doi.org/10.1038 /nclimate2727.

— - and Coauthors, 2017: A meteorological and chemical overview of the DACCIWA field campaign in West Africa in June-July 2016. Atmos. Chem. Phys., 17, 10 893-10 918, https://doi.org/10.5194/acp-17 -10893-2017.

Kuettner, J. P., 1974: General description and central program of GATE. Bull. Amer. Meteor. Soc., 55, 712-719.

Lebel, T., and Coauthors, 2010: The AMMA field campaigns: Multiscale and multidisciplinary observations in the West African region. Quart. J. Roy. Meteor. Soc., 136 (S1), 8-33, https://doi.org/10.1002/qj.486.

Leduc-Leballeur, M., G. De Coëtlogon, and L. Eymard, 2013: Air-sea interaction in the Gulf of Guinea at intraseasonal time-scales: Wind bursts and coastal precipitation in boreal spring. Quart. J. Roy. Meteor. Soc., 139, 387-400, https://doi.org/10.1002/qj.1981.

Mann, J. A. L., J. C. Chiu, R. J. Hogan, E. J. O’Connor, T. S. L'Ecuyer, T. H. M. Stein, and A. Jefferson, 2014: Aerosol impacts on drizzle properties in warm clouds from ARM Mobile Facility maritime and continental deployments. J. Geophys. Res. Atmos., 119, 4136-4148, https://doi.org/10.1002/2013JD021339.

Mülmenstädt, J., O. Sourdeval, J. Delanoë, and J. Quaas, 2015: Frequency of occurrence of rain from liquid-, mixed-, and ice-phase clouds derived from A-Train satellite retrievals. Geophys. Res. Lett., 42, 6502-6509, https://doi.org/10.1002/2015GL064604.

Pan, X. L., and Coauthors, 2011: Correlation of black carbon aerosol and carbon monoxide in the highaltitude environment of Mt. Huang in Eastern China. Atmos. Chem. Phys., 11, 9735-9747, https:// doi.org/10.5194/acp-11-9735-2011.

Parker, D. J., and Coauthors, 2008: The AMMA radiosonde program and its implications for the future of atmospheric monitoring over Africa. Bull. Amer. Meteor. Soc., 89, 1015-1027, https://doi.org /10.1175/2008BAMS2436.1.

Redelsperger, J.-L., C. D. Thorncroft, A. Diedhiou, T. Lebel, D. J. Parker, and J. Polcher, 2006: African Monsoon Multidisciplinary Analysis: An international research project and field campaign. Bull. Amer. Meteor. Soc., 87, 1739-1746, https://doi.org /10.1175/BAMS-87-12-1739.

Schrage, J. M., and A. H. Fink, 2012: Nocturnal continental low-level stratus over tropical West Africa: Observations and possible mechanisms controlling its onset. Mon. Wea. Rev., 140, 1794-1809, https:// doi.org/10.1175/MWR-D-11-00172.1.

Schuster, R., A. H. Fink, and P. Knippertz, 2013: Formation and maintenance of nocturnal low-level stratus over the southern West African monsoon region during AMMA 2006. J. Atmos. Sci., 70, 2337-2355, https://doi.org/10.1175/JAS-D-12-0241.1.

Stein, T. H. M., D. J. Parker, J. Delanoë, N. S. Dixon, R. J. Hogan, P. Knippertz, R. I. Maidment, and J. H. Marsham, 2011: The vertical cloud structure of the West African monsoon: A 4 year climatology using CloudSat and CALIPSO. J. Geophys. Res., 116, 2156-2202, https://doi.org/10.1029/2011JD016029.

Tompkins, A. M., and A. A. Adebiyi, 2012: Using CloudSat cloud retrievals to differentiate satellite-derived rainfall products over West Africa. J. Hydrometeor., 13, 1810-1816, https://doi.org/10.1175/JHM-D-12-039.1. Van der Linden, R., A. H. Fink, and R. Redl, 2015: Satellite-based climatology of low-level continental clouds in southern West Africa during the summer monsoon season. J. Geophys. Res. Atmos., 120, 1186-1201, https://doi.org/10.1002/2014JD022614.

Van Zanten, M. C., B. Stevens, G. Vali, and D. L. Lenschow, 2005: Observations of drizzle in nocturnal marine stratocumulus. J. Atmos. Sci., 62, 88-106, https://doi.org/10.1175/JAS-3355.1.

WMO, 2010: Part A-Alphanumeric codes. Manual on Codes, Vol. I.1, World Meteorological Organization Publ. WMO-306, 506 pp. 